(C) 2021, The Authors. Published by Elsevier Inc. and Fass Inc. on behalf of the American Dairy Science Association ${ }^{\circledR}$. This is an open access article under the CC BY-NC-ND license (http://creativecommons.org/licenses/by-nc-nd/4.0/).

\title{
Economic losses due to Johne's disease (paratuberculosis) in dairy cattle
}

\author{
Philip Rasmussen, ${ }^{1}$ Herman W. Barkema, ${ }^{2}$ Steve Mason, ${ }^{2}$ Eugene Beaulieu, ${ }^{3}$ and David C. Hall ${ }^{1 *}$ \\ ${ }^{1}$ Department of Ecosystem and Public Health, University of Calgary, Calgary, AB, Canada T2N 1N4 \\ ${ }^{2}$ Department of Production Animal Health, University of Calgary, Calgary, AB, Canada T2N 1N4 \\ ${ }^{3}$ Department of Economics, University of Calgary, Calgary, AB, Canada T2N 1N4
}

\begin{abstract}
Johne's disease (JD), or paratuberculosis, is an infectious inflammatory disorder of the intestines primarily associated with domestic and wild ruminants including dairy cattle. The disease, caused by an infection with Mycobacterium avium subspecies paratuberculosis (MAP) bacteria, burdens both animals and producers through reduced milk production, premature culling, and reduced salvage values among MAP-infected animals. The economic losses associated with these burdens have been measured before, but not across a comprehensive selection of major dairy-producing regions within a single methodological framework. This study uses a Markov chain Monte Carlo approach to estimate the annual losses per cow within MAPinfected herds and the total regional losses due to JD by simulating the spread and economic impact of the disease with region-specific economic variables. It was estimated that approximately $1 \%$ of gross milk revenue, equivalent to US $\$ 33$ per cow, is lost annually in MAPinfected dairy herds, with those losses primarily driven by reduced production and being higher in regions characterized by above-average farm-gate milk prices and production per cow. An estimated US $\$ 198$ million is lost due to JD in dairy cattle in the United States annually, US\$75 million in Germany, US\$56 million in France, US\$54 million in New Zealand, and between US $\$ 17$ million and US $\$ 28$ million in Canada, one of the smallest dairy-producing regions modeled.

Key words: paratuberculosis, economic impact, Monte Carlo simulation, Markov process
\end{abstract}

\section{INTRODUCTION}

Johne's disease (JD), or paratuberculosis, is an infectious chronic inflammatory disorder of the intestines that can affect domestic and wild ruminants including dairy cattle (Fecteau and Whitlock, 2010). The disease

Received July 29, 2020.

Accepted October 20, 2020.

*Corresponding author: dchall@ucalgary.ca is caused by an infection with Mycobacterium avium ssp. paratuberculosis (MAP), a bacterial organism that is relatively resistant to environmental, physical, and chemical stressors (Manning and Collins, 2001; Whittington et al., 2004; Donaghy et al., 2009) and that can persist for extended periods outside of its host environment, surviving up to $55 \mathrm{wk}$ in a dry, fully shaded environment (Whittington et al., 2004). Although MAP infection has also been observed in omnivores and carnivores such as wild rabbits (Greig et al., 1999), foxes (Beard et al., 2001), and nonhuman primates (McClure et al., 1987; Zwick et al., 2002), JD is primarily associated with cattle and sheep. As the infection progresses in cattle through its 4 distinct stages, the clinical effects worsen in severity from diarrhea and reduced milk production to lethargy, hypoproteinemia, and severe emaciation (Tiwari et al., 2006). These clinical effects can result in substantial economic losses for dairy producers (Garcia and Shalloo, 2015), with decreased milk production (Lombard et al., 2005; McAloon et al., 2016), decreased slaughter value (Benedictus et al., 1985; Kudahl and Nielsen, 2009; Raizman et al., 2009), and premature culling (Ott et al., 1999; Shephard et al., 2016) among the primary sources. Annual losses per cow among MAP-infected dairy herds in the United States have been estimated at US\$21 (Ott et al., 1999), US\$35 (Groenendaal et al., 2002), and up to US\$79 (Pillars et al., 2009); annual losses among MAP-infected dairy herds in Canada have been estimated at CA $\$ 49$ (approximately US\$40) per cow (Tiwari et al., 2008). Raizman et al. (2009) estimated income over feed cost losses of US\$366 per MAP-shedding cow per lactation, and more recently, Bhattarai et al. (2013) estimated annual losses of US $\$ 1,644$ per 100 cows in a US herd with a true prevalence of $7 \%$.

With the herd-level prevalence of MAP infection likely exceeding $50 \%$ in most countries with significant dairy industries (Barkema et al., 2018), there is a need to estimate the economic losses due to JD across major dairy-producing regions within a single methodological framework. This prospect is complicated by the heterogeneity of both economic characteristics across regions and methodologies across MAP prevalence studies. 
However, the former can be addressed by modeling with region-specific economic variables and the latter by modeling with a range of assumed prevalence scenarios across regions. Accordingly, this study uses Markov chain Monte Carlo methods to (1) model the spread of MAP infection within dairy herds, (2) estimate economic losses due to JD for regions with available prevalence estimates, and (3) estimate economic losses due to JD using a range of assumed prevalence scenarios across a more comprehensive group of major dairy-producing countries, states, and provinces.

\section{MATERIALS AND METHODS}

A MAP-negative Markov model was developed to establish baseline steady-state herd characteristics, followed by a MAP-positive Markov model where herd structure and the distribution of infected animals across age groups changed over time. Using a Monte Carlo simulation approach, MAP-positive herds from each region were compared with baseline MAP-negative herds from each region to generate 3 main sets of results: the general behavior of the model with assumptions of $10 \%$ initial within-herd prevalence and $50 \%$ herd-level prevalence for a generic herd with no region-specific economic variables; estimated losses due to MAP infection for a select group of dairy-producing regions with available prevalence estimates; and estimated losses for a more comprehensive group of dairy-producing regions over a range of assumed prevalence scenarios. Last, the Canadian estimates were reexamined with special consideration for the unique market conditions that arise due to supply management (e.g., fixed annual production levels and relatively high farm-gate prices).

\section{MAP-Negative Models}

A MAP-negative baseline Markov herd model was developed with purchased replacements coming from a separately modeled MAP-negative pool. The herd and replacement pools were modeled using the same constraints and structure: 15 age categories ranging from 0-3 mo to 8-9 yr of age, with each age category having its own matrix of transition probabilities, and the model spanning a 10-period horizon with each period representing $1 \mathrm{yr}$. In the MAP-negative models, animals either age or may be culled until they reach the 8-9 yr category when they must be culled. Natural replacements (aged 0 to $12 \mathrm{mo}$ ) and purchased replacements (aged 12 mo to $3 \mathrm{yr}$ ) are added to the herd each year to maintain the herd's age structure, with the former coming from within the herd and the latter coming from the replacement pool. After the initial age parameters were set, the herd and pool were modeled for fifty 1-yr periods stabilizing with an annual cow-culling rate of $27 \%$, a young-stock percentage (including calves less than one year) of $48 \%$, and for a 100-cow herd, 1.36 cows and 3.07 young-stock between 1 and 2 yr of age being brought in from the external replacement pool each year. These numbers are similar to those observed in Canadian dairy herds, which have an average cowculling rate between $26 \%$ and 33\% (OMAFRA, 2020), an average young-stock percentage of $48 \%$ (STATCAN, 2020), and purchase an average of 1.37 cows and 3.09 young-stock between 1 and 2 yr of age per 100 cows per year (Van Biert, 2019).

\section{MAP-Positive Models}

Whereas the MAP-negative models had only 2 possible outcomes in each age group's transition matrix (i.e., continue aging or be culled), the MAP-positive models are more complex. Infection with MAP is characterized by a long incubation period (Jubb et al., 2004; Fecteau and Whitlock, 2010), with varying levels of susceptibility across age groups (Windsor and Whittington, 2010; Mortier et al., 2013) and shedding across stages of infection (Weber et al., 2010; Mitchell et al., 2012; Mortier et al., 2014; Wolf et al., 2015). The modeling implications of these characteristics will be expanded upon later in this section. However, in general terms, the MAP-positive models function in the following way: the animal can remain negative and continue aging, become infected and continue aging, or be culled. Once an animal is infected, it can either be culled or its infection can undergo progression, regression, or inertia (remain the same). Animals in each stage of infection are associated with a different risk of being culled, and within each stage, there are various nonshedding, lightly shedding, moderately shedding, and heavily shedding states. Infection pressure on animals in the herd $f_{t}$ is determined by the number and degree of shedding animals in the herd in period $t$, defined as

$$
\begin{aligned}
& \text { infection pressure }=f_{t}= \\
& \frac{M A P_{l} \times L_{t}+M A P_{m} \times M_{t}+M A P_{h} \times H_{t}}{\text { animals }},
\end{aligned}
$$

where $M A P_{l}, M A P_{m}$, and $M A P_{h}$ equal the amount of MAP bacteria shed by lightly shedding, moderately shedding, and heavily shedding animals, respectively. $L_{t}, M_{t}$, and $H_{t}$ equal the number of animals shedding at those levels in period $t$, and animals equals the total number of animals in the herd, which is fixed over the 10-period horizon.

All other potential outcomes are functions of infection pressure $f_{t}$ and compete for the probability of 
remaining in the herd equal to $(1-x)$, where $x$ is the probability of being culled. For MAP-negative animals, the probability of being culled remains the steady-state value according to their age category. For MAP-positive animals, the probability of being culled depends on the stage of their infection, with the probability increasing with the severity of infection. In their general forms across all time periods, the transition probability $P$ for each outcome within each age-specific transition matrix can be defined as

$$
\begin{aligned}
& P(\text { infection })=\left(1-e^{-\sum_{i=0}^{n} f_{i} \times w}\right) \times \frac{f}{\sum_{i=0}^{n} f_{i}} \times(1-x), \\
& P(\text { progression })= \\
& \left(1-e^{-\sum_{i=0}^{n}\left(f_{i}+\frac{1}{f_{i}}\right) \times w}\right) \times \frac{f}{\sum_{i=0}^{n}\left(f_{i}+\frac{1}{f_{i}}\right)} \times(1-x), \\
& P(\text { regression })= \\
& \left(1-e^{-\sum_{i=0}^{n}\left(f_{i}+\frac{1}{f_{i}}\right) \times w}\right) \times \frac{\frac{1}{f}}{\sum_{i=0}^{n}\left(f_{i}+\frac{1}{f_{i}}\right)} \times(1-x), \\
& P(\text { inertia })=\left(e^{-\sum_{i=0}^{n}\left(f_{i}+\frac{1}{f_{i}}\right) \times w}\right) \times \frac{(1-x)}{a},
\end{aligned}
$$

where $n$ is the number of potential outcomes given an animal's age and stage of infection; $P$ (infection $)$ is the probability of an animal transitioning from a MAPnegative stage to the initial stage of infection (the probability of infection); $P$ (progression) is the probability of transitioning from one stage of infection to a more severe stage (the probability of disease progression); $P$ (regression) is the probability of transitioning from one stage of infection to a less severe stage (the probability of disease regression); and $P($ inertia $)$ is the probability of transitioning to the same stage of infection (the probability of neither disease progression nor regression occurring). There is a positive relationship between infection pressure $f$ and $P($ infection $)$, and there is a positive relationship between infection pressure $f$ and $P($ progression $)$ and a negative relationship between infection pressure $f$ and $P$ (regression). This reflects the observed association between environmental MAP load and the rate of disease progression (Weber et al.,
2010; Windsor and Whittington, 2010; Bolton et al., 2011), including repeated exposure to MAP (Fecteau et al., 2010; McGregor et al., 2012; Suwandi et al., 2017; Marquetoux et al., 2018). Note that this differs from explicitly modeling initial infectious dose dependence, which would require complicated tracking of infected animals through time not readily accomplished within a Markov framework. However, the modeling approach employed here still captures the positive feedback between within-herd prevalence, infection pressure, and the rate of infection progression. Last, by definition, there is a negative relationship between the sum of all infection, progression, and regression probabilities and $P($ inertia $)$ because the more likely the stage of infection is to change over one transition period, the less likely it is to remain unchanged. In Equation [5], $a$ is the number of potential inertia outcomes where transitions would only occur to another state (level of shedding) within the same stage of infection (e.g., a transition from a nonshedding state of stage 3 infection to a moderately shedding state of stage 3 infection). In Equations [2] through [5], $w$ is a weight that allows for adjustment in the rate of spread of MAP infection within the herd. For this study, $w$ was set it at 0.075 , which through trial and error was determined to result in an approximate doubling of within-herd prevalence over $10 \mathrm{yr}$. However, by adjusting this value, other within-herd prevalence scenarios could be modeled, from scenarios where prevalence remains relatively constant over 10 yr to explosive epidemics where prevalence increases dramatically.

To accurately reflect MAP's infectivity-age relationship, its long incubation period, and its clinical progression, limits on the ranges of possible outcomes were set within each age group's transition matrix as well as the potential states of shedding across stages: infected animals up to 12 mo old can only be in stage 1 of infection (the initial stage of infection where animals are infected and may shed low levels of MAP bacteria); infected animals up to 24 mo old can be in stages 1 or 2 (stage 2 being the subclinical stage where animals appear healthy but may shed low and moderate levels of bacteria); from 2 to $5 \mathrm{yr}$ old they can be in stages 1,2 , or 3 (stage 3 being the clinical stage of infection where animals may exhibit clinical symptoms such as intermittent diarrhea and weight loss and may begin to shed low, moderate, and high levels of bacteria); animals 5 to 9 yr old can be in all stages of infection, with the final stage of infection, stage 4 (the terminal stage characterized by severe emaciation, often mandibular edema, and high levels of shedding), being a de facto absorptive stage that most often results in culling within one period; all stages of infection have possible nonshedding states within them except stage 4; animals 
can only become infected in their first $12 \mathrm{mo}$; once an animal is MAP-positive they will remain positive for their lifetime; and progression or regression can only transition the animals to within one stage of their current stage of infection. For example, a "12-15 month" calf that is MAP-positive in stage 2 of infection can either progress to stage 3, regress to stage 1, remain in stage 2 , or be culled within 1 yr. Similarly, a " $5-6$ year" cow in stage 3 of infection can either progress to stage 4 , regress to stage 2 , remain in stage 3 , or be culled within 1 yr. Examples of the initial period 0 herd structure matrix, the period 0 transition matrices for animals aged $0-3 \mathrm{mo}, 2-3 \mathrm{yr}$, and $8-9 \mathrm{yr}$, and the final period 1 herd structure matrix for the MAP-positive model, are available in Supplemental Tables S1-S5 (https://doi.org/10.5683/SP2/6OXE0R).

\section{Monte Carlo Simulations}

Monte Carlo simulations are a type of methodology that uses random sampling from a set of input variables, each with their own distributions, to determine a range of possible outcomes. In this case 10,000 iteration simulations were run using randomized variables in a Markov model according to the mean and distribution associated with each variable. For the MAP-specific variables in the model (Table 1), all variables were assumed to have normal distributions with standard deviations of $10 \%$ of their mean values. However, for the initial within-herd prevalence and initial regional cow-level prevalence, a set of herd conditions (disease distributions) was required for each potential initial value randomly selected in each of the 10,000 iterations. To obtain these initial conditions, MAP-positive replacements were introduced into the steady-state MAP-negative herd and fifty 1 -yr periods were simulated using the MAP-positive model transition probabilities previously described. As prevalence increased over time in this 50-yr simulation, the distribution of infected animals in the herd changed, generating a range of disease distributions for every iteration within each subsequent 10-yr simulation. This model initialization allowed for within-herd and regional cow-level prevalence to be simulated with normal distributions and standard deviations equal to $20 \%$ of the mean. Although these assumed standard deviations may seem constrictive, data required to determine their true values were unavailable and the selected standard deviations capture a wide range of input values without destabilizing the simulations and their results.

Table 1. Input variables used in for the Monte Carlo simulations of the Mycobacterium avium ssp. paratuberculosis-positive Markov herd model ${ }^{1}$

\begin{tabular}{|c|c|c|c|}
\hline Variable & Mean value & Unit & Source \\
\hline Replacement pool & $5,000.00$ & Cows & Assumed \\
\hline Replacement cost (labor) & 2.00 & $\mathrm{~h}$ & Assumed \\
\hline Bacteria shed, moderate shedders ${ }^{2}$ & 25.00 & $\mathrm{cfu}$ & Whitlock et al. (2000) and Crossley et al. (2005) \\
\hline Bacteria shed, heavy shedders ${ }^{2}$ & 50.00 & cfu & Whitlock et al. (2000) and Crossley et al. (2005) \\
\hline Weight at 0 to $3 \mathrm{mo}$ & 74.24 & $\mathrm{~kg}$ & Jones and Heinrichs (2017) \\
\hline Weight at 9 to $12 \mathrm{mo}$ & 286.52 & $\mathrm{~kg}$ & Jones and Heinrichs (2017) \\
\hline Weight at 12 to $15 \mathrm{mo}$ & 354.86 & $\mathrm{~kg}$ & Jones and Heinrichs (2017) \\
\hline Weight at 15 to $18 \mathrm{mo}$ & 425.32 & $\mathrm{~kg}$ & Jones and Heinrichs (2017) \\
\hline Weight at 18 to $21 \mathrm{mo}$ & 477.63 & $\mathrm{~kg}$ & Jones and Heinrichs (2017) \\
\hline Weight at 21 to $24 \mathrm{mo}$ & 524.05 & $\mathrm{~kg}$ & Jones and Heinrichs (2017) \\
\hline Weight at maturity ( 2 to $9 \mathrm{yr}$ ) & 680.39 & $\mathrm{~kg}$ & Jones and Heinrichs (2017) \\
\hline Value reduction, stage 4 animals & 31.0 & $\%$ & Kudahl and Nielsen (2009) \\
\hline Culling risk, stage 2 animals $^{4}$ & 2.69 & Ratio & Calculated \\
\hline Culling risk, stage 1 animals $^{4}$ & 1.08 & Ratio & Calculated \\
\hline
\end{tabular}

${ }^{1}$ All variables simulated with a normal distribution and a standard deviation of $10 \%$ of the mean.

${ }^{2}$ Light and moderate shedding values based on median cfu count for the range. Heavy shedders at minimum cutoff.

${ }^{3}$ Based on stage 4 value reduction observed in study. Other values estimated by scaling the stage 4 value to a truncated cumulative logistic probability distribution (maximum $=0.308, \alpha=0.308, \beta=0.031$ ).

${ }^{4}$ Based on stage 4 hazard ratio observed in the study. Other values estimated by scaling the stage 4 value to a truncated cumulative logistic probability distribution (maximum $=3.200, \alpha=3.200, \beta=0.320$ ). Stage 1 risk is based on a mean value of 1.00 with a normal distribution and standard deviation of 0.10 , truncated with a minimum value of 1.00 to obtain a true mean of 1.08 . 


\section{Economic Losses}

To estimate region-specific economic losses, regionspecific economic input variables were incorporated into the simulations. Detailed values are available in Appendix Tables A1 and A2. After each period, the MAP-positive herd was compared with the steady-state MAP-negative herd to estimate the economic losses per cow within infected herds due to MAP infection. Premature culling losses were estimated by tallying additional exits in the MAP-positive herd and assigning those exits a value according to their age-at-exit and associated replacement price. Additional aggregated labor costs of seeking out, purchasing, and introducing a replacement to the herd were also accounted for. Salvage losses were estimated by tallying MAP-positive exits and assigning them a reduced salvage value according to their stage of infection. Production losses were estimated by tallying the number of MAP-positive cows and determining the quantity of milk that would have been produced if those cows were negative instead, multiplied by the farm-gate price for milk. The sum of these 3 losses was divided by the number of cows in the herd to obtain an estimate of total losses per cow within MAP-infected herds. Total regional losses were estimated by the product of regional head count, herd-level prevalence, and total losses per cow in infected herds. Annual losses, both per cow and regional, were discounted over time at an assumed rate of $5 \%$ per annum and then averaged over the 10-yr horizon to obtain the reported annual loss estimates. This discount rate was selected because it is consistent with small private firm investment in a family enterprise; it falls between a public investment return rate of approximately 3\% (USDA, 2020) and a private investment return rate of approximately $10 \%$ (Macrotrends, 2020). Similarly, the Treasury Board of Canada selected a discount rate of $7 \%$ in its 2007 CostBenefit Analysis Guide but noted that it would likely be reduced in future years (Treasury Board of Canada, 2007). Finally, 2 main sets of simulations were run: one using available prevalence estimates (Table 2) for a limited number of regions, and a second using a range of assumed prevalence scenarios for a comprehensive selection of major dairy-producing regions.

\section{RESULTS}

\section{General Behavior}

With a mean initial within-herd prevalence of $10 \%$ and a mean initial regional herd-level prevalence of $50 \%, 90 \%$ of the 10,000 iterations resulted in proportional increases of within-herd prevalence ranging from 0.51 to 1.67 , with a mean of 1.02 , which is ap- proximately equivalent to a doubling of within-herd prevalence from $10 \%$ to $20 \%$ over 10 yr (Figure 1). The percentage of infected animals that shed MAP increased from $6 \%$ to $12 \%$ over the 10 -yr horizon, with the percentage of moderately and heavily shedding animals steadily increasing from $6 \%$ to over $10 \%$ of all shedding animals by yr 10 (Figure 2). As prevalence increased, so did infection pressure and the severity of infections, resulting in an increased cow-culling rate relative to the steady-state MAP-negative cow-culling rate (Figure 3A). Although this increased culling rate is indicative of worsening overall health in the herd, the precise sources of potential economic losses in the model (i.e., premature culling, reduced salvage value, and reduced production) can be seen changing over the 10-yr horizon in Figure 3B: the percentage of MAPpositive culls with varying degrees of reduced salvage value increased from just over $7 \%$ to $12 \%$ of all culls; the percentage of premature culls directly attributable to MAP infection doubled from $2 \%$ to $4 \%$ of all culls; forgone production as a percentage of total production increased from $0.63 \%$ to $1.16 \%$.

\section{Economic Losses (Available Prevalence Estimates)}

On a national herd basis, estimated annual losses per cow within MAP-infected herds based on available prevalence estimates ranged from US $\$ 15.07$ in the Netherlands to US $\$ 48.91$ in Canada, and as a percentage of gross milk revenue on MAP-infected farms, from $0.39 \%$ in the Netherlands to $1.91 \%$ in Ireland. Total annual national losses ranged from US $\$ 1.91$ million in Austria to US\$150.19 million in Germany (Table 3).

\section{Economic Losses (Assumed Prevalence)}

With an assumed within-herd prevalence of $10 \%$ in MAP-infected herds and a herd-level prevalence of $50 \%$ across major dairy-producing regions, annual losses per cow in infected herds ranged from US $\$ 8.31$ in Brazil to US\$81.53 in Japan, with a revenue-weighted average of US\$32.84 per cow per year. Annual national herd losses ranged from US\$5.84 million in Finland to US\$198.42 million in the United States. Revenue-weighted average losses as a percentage of gross milk revenue were $1.07 \%$, with significantly higher estimates for Ireland, New Zealand, and Australia (Table 4). Results for a wider range of prevalence scenarios are presented in Appendix Table A3. When annual losses are broken down into their component sources, premature culling losses ranged from $14 \%$ of total losses in Poland and Russia to $34 \%$ in New Zealand and Australia, reduced salvage value losses ranged from $6 \%$ in Poland to $19 \%$ in Ireland, and production losses ranged from $40 \%$ in 
Ireland to $80 \%$ in Poland. Revenue-weighted averages premature culling losses accounted for $24 \%$ of total losses, reduced salvage value losses accounted for $11 \%$, and production losses accounted for $65 \%$. Details of the breakdown of total losses into source components for all regions modeled are available in Appendix Table A4.

Annual losses due to MAP infection were also estimated with an assumed stable within-herd prevalence of $10 \%$ and the same stable herd-level prevalence of $50 \%$. Similar results were observed (Table A5): annual losses per cow in infected herds ranged from US $\$ 7.30$ in Brazil to US $\$ 71.57$ in Japan, and annual national herd losses ranged from US\$4.87 million in Czechia to $\$ 171.92$ million in the United States. Losses per cow as a percentage of gross milk revenue ranged from $0.78 \%$ in Czechia to $1.40 \%$ in Ireland, with a revenue-weighted average of $0.93 \%$. Compared with the estimated losses within the dynamic 10-yr prevalence models, the singleyear stable prevalence (and therefore non-discounted) losses per cow were between 10 and $16 \%$ less, and annual regional losses were between 11 and $16 \%$ less, with revenue-weighted average differences of $13 \%$ for both per-cow and per-region annual losses.

\section{Economic Losses (Canada)}

This section reexamines the results for Canada with special consideration for the implications of supply management; production losses are no longer calculated as forgone production, but instead as the cost of having additional cows to maintain a fixed level of production over the 10-yr horizon. With assumed prevalence values

Table 2. Available herd-level and regional cow-level Mycobacterium avium ssp. paratuberculosis (MAP) prevalence estimates for various dairyproducing regions

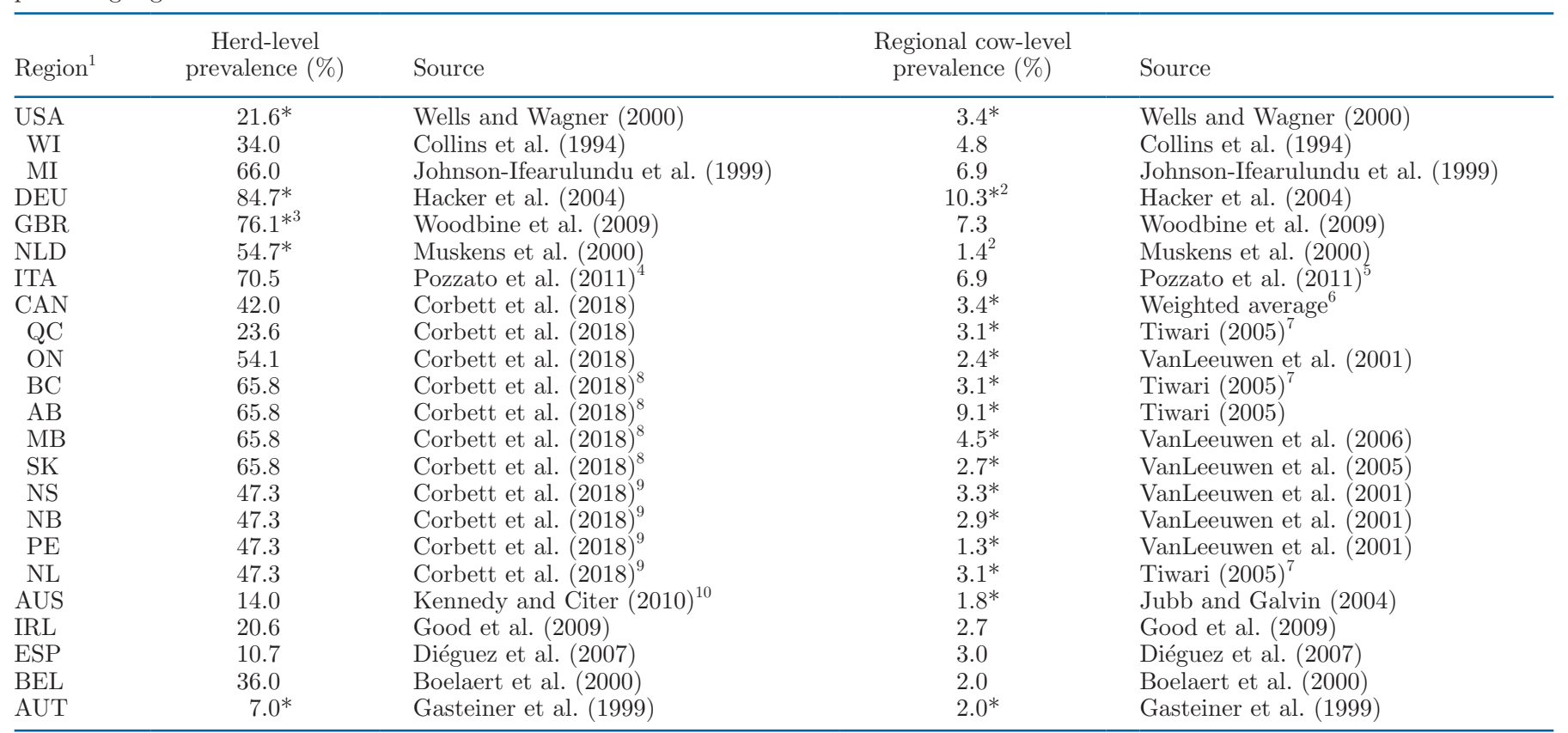

${ }^{1} \mathrm{USA}=$ United States; WI = Wisconsin; MI = Michigan; DEU = Germany; GBR = Great Britain; NLD = the Netherlands; ITA = Italy; CAN $=$ Canada; $\mathrm{QC}=$ Québec ON = Ontario; $\mathrm{BC}=$ British Columbia; $\mathrm{AB}=$ Alberta $\mathrm{MB}=$ Manitoba; $\mathrm{SK}=$ Saskatchewan; NS = Nova Scotia; $\mathrm{PE}=$ Prince Edward Island; NL = Newfoundland; AUS = Australia; IRL = Ireland; ESP = Spain; BEL = Belgium; AUT = Austria

${ }^{2}$ Because the simulations include both a regional replacement pool and a MAP-positive herd, both regional cow-level prevalence estimates and within-herd prevalence estimates were required. Most prevalence studies referenced provided only herd-level and regional cow-level estimates. The following equality was used to convert prevalence estimates between the various types: $p_{w}=p_{r} / p_{h}$, where $p_{w}, p_{r}$, and $p_{h}$, equal within-herd, regional cow-level, and herd-level prevalence, respectively.

${ }^{3}$ Herd-weighted average of results from first, second, and third tests.

${ }^{4}$ Average of Lombardy and Veneto regions and weighted by herds sampled in study.

${ }^{5}$ Calculated from reported within-herd prevalence for Lombardy and Veneto regions, weighted by head of cattle sampled in each region.

${ }^{6}$ Average of Canadian cow-level estimates weighted by head of cattle in each province.

${ }^{7}$ Tiwari (2005) Canadian cow-level prevalence estimate.

${ }^{8}$ Corbett et al. (2018) estimate for Canadian western provinces.

${ }^{9}$ Corbett et al. (2018) estimate for Canadian Atlantic provinces.

${ }^{10}$ Herd-level prevalence in control region (Victoria).

*Apparent prevalence estimate. 
of $10 \%$ within infected herds and $50 \%$ of herds being infected, annual losses per cow ranged from US $\$ 28.48$ in Prince Edward Island to US\$53.16 in Newfoundland, and annual provincial losses ranged from US\$160,000 in Newfoundland to US\$5.73 million in Québec (Table 5). Expanded results with fixed annual production are available in the Appendix; the breakdown of total losses per cow into their source components is available in Table A6, and results for a wider range of prevalence scenarios are available in Table A7.

\section{Sensitivity Analyses}

For simplicity, an average Canadian herd with an assumed initial within-herd prevalence of $10 \%$ and an assumed herd-level prevalence of $50 \%$ in the region has been selected. Changes in estimated losses per cow were most sensitive to changes in within-herd prevalence, followed by annual production per cow, the farm-gate price, the effect of MAP infection on production, and the amount of bacteria shed by lightly shedding animals
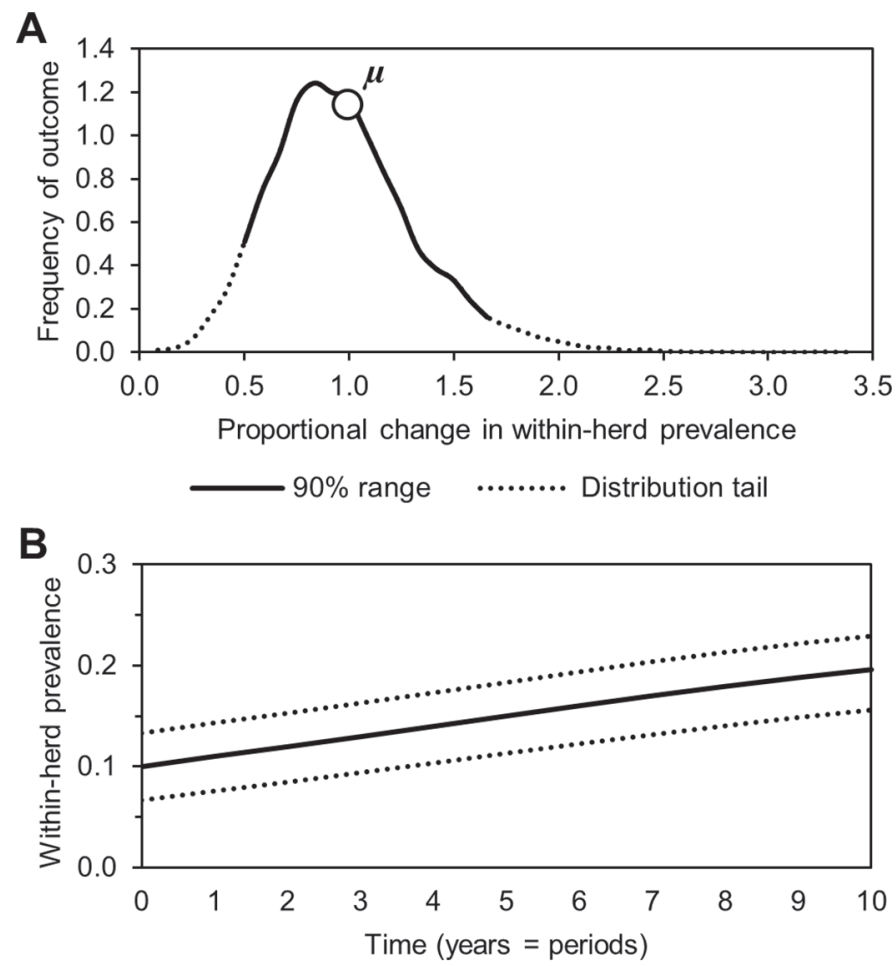

Within-herd prevalence

$90 \%$ range

Figure 1. Simulated changes in within-herd Mycobacterium avium ssp. paratuberculosis (MAP) prevalence over time (10,000 iterations) assuming initial mean values of $10 \%$ within-herd prevalence and $50 \%$ herd-level prevalence. (A) Distribution of proportional changes in within-herd prevalence over a 10-yr horizon with distribution mean identified by $\mu$. (B) Within-herd prevalence and its $90 \%$ confidence interval over time.
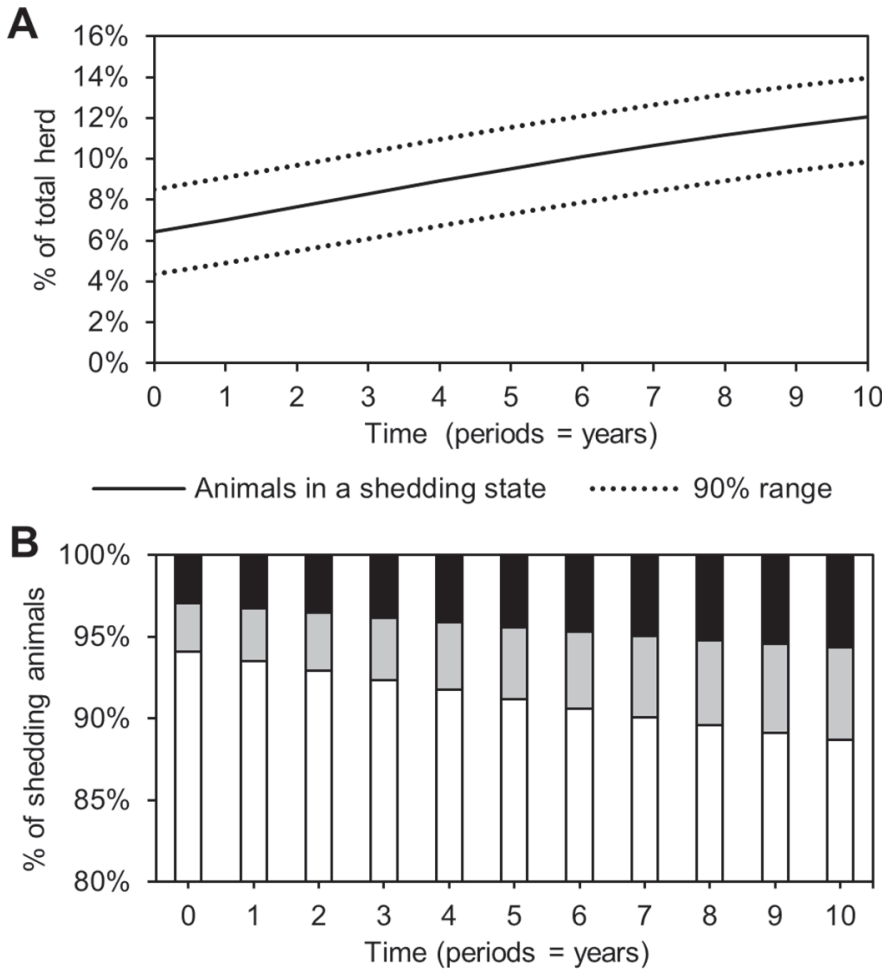

口lightly shedding $\square$ moderately shedding $\mathbf{m e a v i l y ~ s h e d d i n g ~}$

Figure 2. Simulated changes in Mycobacterium avium ssp. paratuberculosis (MAP) shedding among animals over time (10,000 iterations) assuming initial mean values of $10 \%$ within-herd prevalence and $50 \%$ herd-level prevalence. (A) Animals in a MAP-shedding state as a percentage of total herd. (B) Degrees of shedding among MAPshedding animals.

(Figure 4). The latter 4 variables had a similar effect on estimated losses per cow, which was significantly less than the effect of within-herd prevalence. Regional loss estimates were sensitive to similar variables, but most sensitive to herd-level prevalence. Premature culling losses were most sensitive to the culling risk associated with stage 1 MAP infection, whereas losses due to reduced salvage values and reduced production were most sensitive to within-herd prevalence. Annual production per cow, volume of bacteria shed by lightly shedding animals, effect of infection on production, and additional culling risk to stage 2 infected animals were also influential variables (Figure 5).

\section{DISCUSSION}

There are 2 main sets of results from this research: first, results for the limited group of regions for which prevalence estimates are available, and second, results for the more comprehensive group of dairy-producing regions with assumed prevalence scenarios. The estimates from the first set may be useful on a region-by- 
A
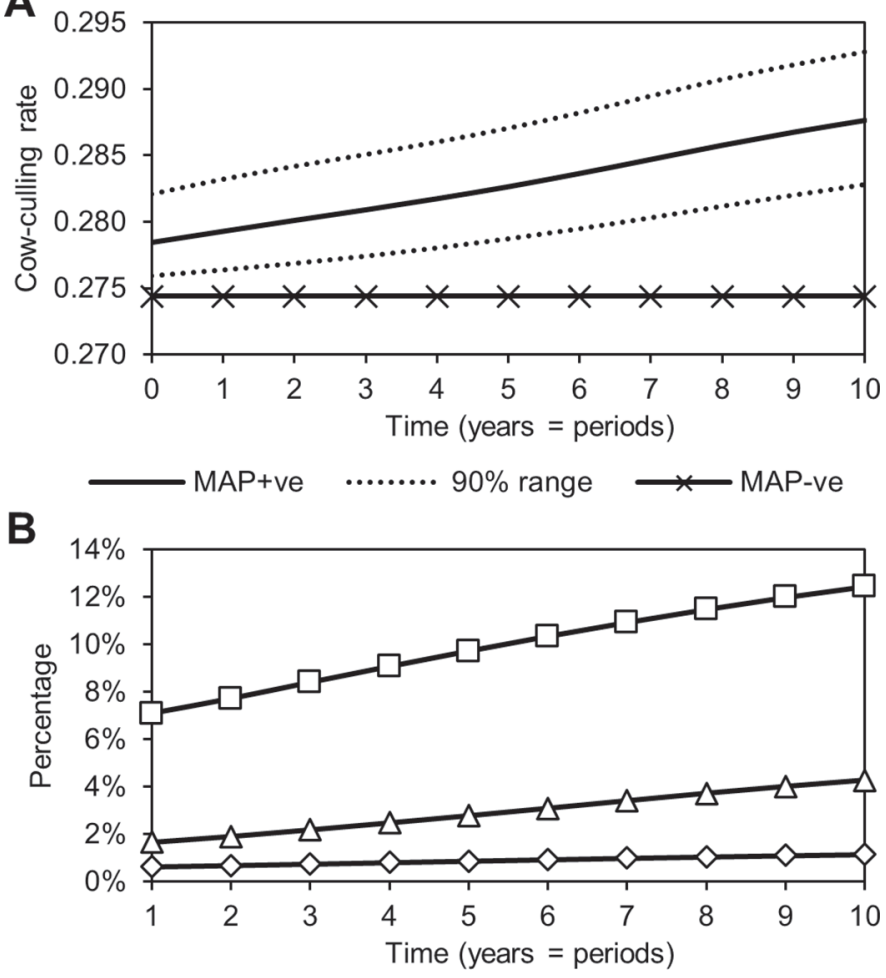

$\longrightarrow$ premature culls $\longrightarrow$ - MAP+ve culls $\longrightarrow$ forgone $\mathrm{kg}$

Figure 3. Simulated changes in indicators of overall herd health over time (10,000 iterations) assuming initial mean values of $10 \%$ within-herd prevalence and $50 \%$ herd-level Mycobacterium avium ssp. paratuberculosis (MAP) prevalence. (A) Cow-culling rate compared with the MAP-negative (MAP-ve) herd over time. (B) Premature culls and MAP-positive (MAP+ve) culls as a percentage of total exits, and forgone production as a percentage of potential production.

region basis if the prevalence estimates they are based on reflect the true prevalence of MAP infection in those regions. However, relying on these prevalence estimates to valuate JD's economic impact across regions is problematic. Because estimated losses are highly dependent on prevalence and prevalence estimates are heterogeneously derived across studies with no centrally accepted quality assurance and quality control standards in widespread use, it is not possible to confidently compare prevalence estimates across regions. Therefore, variations in estimated losses across regions based on available prevalence estimates may reflect variations across prevalence studies as opposed to variations in economic losses due to JD.

As an example, refer to the first set of results for Germany and the Netherlands using available prevalence estimates. The neighboring countries have many similar key dairy sector characteristics with above-average annual production per cow per year, similar farm-gate prices, aggregated wage rage rates, replacement costs, and other such production variables. Due to the geo- graphic proximity, level of integration, and similarity of economic characteristics across the 2 dairy industries, it would be intuitively reasonable to expect Germany and the Netherlands to not only have comparable MAP prevalence, but also for MAP infection to have a comparable per cow economic impact on their dairy sectors. However, based on available prevalence estimates, Germany has a herd-level prevalence of $85 \%$ and a within-herd prevalence $12.2 \%$ (Hacker et al., 2004), whereas the Netherlands has a herd-level prevalence of $55 \%$ and a within-herd prevalence of $2.5 \%$ (Muskens et al., 2000). As a result, estimated losses per cow on infected farms across the 2 regions are significantly different: MAP-infected farms in Germany are estimated to lose US $\$ 43.08$ per cow per year, or $1.41 \%$ of gross milk revenue, whereas infected farms in the Netherlands are estimated to lose only US $\$ 15.07$ per cow per year, or $0.39 \%$ of gross milk revenue. However, when instead using the assumed prevalence scenario of $10 \%$ within MAP-infected herds and $50 \%$ of herds being infected, there are much closer estimates for the 2 countries: US $\$ 36.40$ and US $\$ 42.82$ per cow for Germany and the Netherlands, respectively, both accounting for $1.11 \%$ of gross milk revenue. There is a similar situation when comparing the 2 largest dairy-producing provinces in Canada: Québec and Ontario. The neighboring regions share many dairy characteristics, have relatively similar regional cow-level prevalence estimates of 3.1\% (Tiwari, 2005) and 2.4\% (VanLeeuwen et al., 2001), but have significantly different herd-level prevalence estimates of $24 \%$ and 54\% (Corbett et al., 2018) for Québec and Ontario, respectively. Based on these herd-level and regional cow-level prevalence estimates, Québec would have a mean within-herd prevalence of $13 \%$ on infected farms, whereas Ontario would have a mean within-herd prevalence of $4 \%$. As a result, infected herds in Québec are estimated to lose US\$60.29 per cow per year or $1.09 \%$ of gross milk revenue, whereas infected farms in Ontario are estimated to lose just US $\$ 30.77$ per cow per year or $0.56 \%$ of gross milk revenue. When prevalence is instead assumed to be uniform across the 2 regions, estimated losses are US $\$ 56.99$ and US $\$ 55.35$, or $0.97 \%$ and $1.01 \%$ of revenue for Québec and Ontario, respectively. By using assumed prevalence scenarios across regions, the differences in estimated losses can be wholly attributed to differences in the economic characteristics of the dairy sectors in the 2 regions.

In the assumed prevalence simulations, the revenueweighted average losses per cow in MAP-positive herds are approximately $1 \%$ of gross milk revenue. Production per cow and farm-gate price are positively related to production losses, which account for an average of $65 \%$ of total losses. However, for certain countries such as Ireland, New Zealand, and Australia, which have 
Table 3. Estimated 10-yr average annual losses (US\$) due to Mycobacterium avium ssp. paratuberculosis infection for various dairy-producing regions based on available prevalence estimates

\begin{tabular}{|c|c|c|c|c|c|c|}
\hline \multirow{2}{*}{$\frac{\text { Region }^{1}}{\text { USA }}$} & \multicolumn{2}{|c|}{$\begin{array}{l}\text { Positive herds, losses } \\
\text { per cow }(90 \% \mathrm{CI})\end{array}$} & \multicolumn{2}{|c|}{$\begin{array}{l}\text { Positive herds, losses as \% } \\
\text { of milk revenue (90\% CI) }\end{array}$} & \multicolumn{2}{|c|}{$\begin{array}{l}\text { Regional losses in } \\
\text { millions }(90 \% \mathrm{CI})\end{array}$} \\
\hline & 53.30 & $(38.49-68.51)$ & 1.41 & $(1.02-1.81)$ & 107.92 & (63.67-160.18) \\
\hline WI & 47.60 & $(33.98-61.83)$ & 1.22 & $(0.87-1.58)$ & 20.67 & $(11.95-30.92)$ \\
\hline MI & 43.02 & $(30.02-57.40)$ & 1.00 & $(0.70-1.34)$ & 12.07 & $(6.81-18.27)$ \\
\hline DEU & 43.08 & $(30.46-56.25)$ & 1.32 & $(0.93-1.72)$ & 150.19 & $(85.82-225.82)$ \\
\hline GBR & 34.40 & $(23.82-45.69)$ & 1.07 & $(0.74-1.42)$ & 49.38 & $(27.62-74.86)$ \\
\hline NLD & 15.07 & $(9.52-21.40)$ & 0.39 & $(0.25-0.55)$ & 12.85 & $(6.82-20.35)$ \\
\hline ITA & 33.45 & $(22.81-44.78)$ & 1.04 & $(0.71-1.39)$ & 40.05 & $(22.48-60.81)$ \\
\hline CAN & 48.91 & $(33.41-65.85)$ & 0.86 & $(0.59-1.16)$ & 20.02 & $(11.28-30.63)$ \\
\hline $\mathrm{QC}$ & 60.29 & $(42.91-78.80)$ & 1.09 & $(0.78-1.43)$ & 5.05 & $(2.94-7.56)$ \\
\hline ON & 30.77 & $(19.73-42.86)$ & 0.56 & $(0.36-0.78)$ & 5.41 & $(2.86-8.47)$ \\
\hline $\mathrm{BC}$ & 37.52 & $(24.56-51.92)$ & 0.59 & $(0.39-0.82)$ & 2.08 & $(1.13-3.24)$ \\
\hline $\mathrm{AB}$ & 84.04 & (59.59-110.12) & 1.37 & $(0.97-1.79)$ & 4.39 & $(2.53-6.61)$ \\
\hline MB & 44.46 & $(29.48-60.85)$ & 0.75 & $(0.50-1.03)$ & 1.21 & $(0.67-1.85)$ \\
\hline SK & 33.17 & $(21.61-46.03)$ & 0.55 & $(0.36-0.76)$ & 0.64 & $(0.34-1.00)$ \\
\hline NS & 37.09 & $(23.49-51.93)$ & 0.66 & $(0.42-0.92)$ & 0.38 & $(0.20-0.60)$ \\
\hline NB & 36.21 & $(24.29-49.73)$ & 0.68 & $(0.45-0.93)$ & 0.33 & $(0.18-0.51)$ \\
\hline $\mathrm{PE}$ & 19.56 & $(12.47-27.81)$ & 0.35 & $(0.22-0.49)$ & 0.13 & $(0.07-0.21)$ \\
\hline NL & 57.59 & $(38.78-78.26)$ & 0.76 & $(0.51-1.03)$ & 0.16 & $(0.09-0.25)$ \\
\hline AUS & 31.25 & $(22.05-40.38)$ & 1.53 & $(1.08-1.97)$ & 6.68 & $(3.88-9.95)$ \\
\hline IRL & 42.81 & $(30.21-55.52)$ & 1.91 & $(1.35-2.48)$ & 12.09 & $(7.02-17.96)$ \\
\hline ESP & 45.99 & $(35.57-57.52)$ & 1.39 & $(1.08-1.74)$ & 4.03 & $(2.48-5.79)$ \\
\hline BEL & 21.72 & $(14.28-29.62)$ & 0.72 & $(0.48-0.99)$ & 4.15 & $(2.26-6.43)$ \\
\hline AUT & 51.21 & $(41.13-61.75)$ & 1.84 & $(1.48-2.22)$ & 1.91 & $(1.19-2.71)$ \\
\hline
\end{tabular}

${ }^{1} \mathrm{USA}=$ United States; $\mathrm{WI}=$ Wisconsin; $\mathrm{MI}=$ Michigan; $\mathrm{DEU}=$ Germany; GBR $=$ Great Britain; NLD $=$ the Netherlands; ITA = Italy; $\mathrm{CAN}=$ Canada; $\mathrm{QC}=$ Québec; $\mathrm{ON}=$ Ontario; $\mathrm{BC}=$ British Columbia; $\mathrm{AB}$ $=$ Alberta; $\mathrm{MB}=$ Manitoba; $\mathrm{SK}=$ Saskatchewan; $\mathrm{NS}=$ Nova Scotia; $\mathrm{PE}=$ Prince Edward Island; $\mathrm{NL}=$ Newfoundland; AUS = Australia; IRL = Ireland; ESP = Spain; BEL = Belgium; AUT = Austria.

above-average losses as a percentage of milk revenue, there are interesting underlying structural factors that contribute to the variation across estimates; these 3 countries have average to below-average annual production per cow and farm-gate prices in conjunction with on-average replacement and salvage prices. This combination results in relatively lower milk revenue and therefore production losses, and the values of premature culling and salvage losses having disproportionate effects on total losses relative to other countries. On average for all countries, premature culling and salvage losses account for $24 \%$ and $11 \%$ of total losses, respectively, but in Ireland, New Zealand, and Australia, they account for $34 \%$ to $41 \%$ and $16 \%$ to $19 \%$, respectively.

The proportional increase in within-herd MAP prevalence over time is perhaps the most important parameter that is not directly identified by the sensitivity analyses; it is the driver of all estimated economic losses because of its effect on within-herd prevalence. As previously mentioned, it was assumed that withinherd MAP prevalence would, on average, double from its initial value over $10 \mathrm{yr}$. Because future losses are discounted over time, the greater losses resulting from the higher within-herd prevalence toward the end of the horizon had less of an effect on the 10-yr average annual losses than the relatively lesser losses in the early years. When within-herd prevalence was instead assumed to be stable at $10 \%$, estimated losses decreased by a revenue-weighted average of $13 \%$ relative to the estimates obtained from the 10-yr dynamic prevalence models, but similar patterns emerged across regions and the magnitude of the losses were comparable. Other key input variables were revealed through the sensitivity analyses, aside from within-herd and herd-level prevalence, production per cow, and farmgate price. Not surprisingly, the effect of MAP infection on production is a significant variable for estimated production losses, which account for most of losses per cow, and therefore regional losses due to MAP infection. The bacterial output of lightly MAP-shedding animals was also identified as a significant source of variation in both estimated total losses and sources of losses, particularly for premature culling losses and reduced salvage value losses. Another interesting input variable is the probability of culling associated with subclinical stage 1 MAP infections. This variable was negatively related to all components of total losses aside from premature culling losses. Although this may seem counterintuitive at first, it is logical. The most severe economic damages would occur at later stages of the disease once clinical signs emerge, but most infected animals in the herd are in the subclinical stage. As the risk of stage 1 animals being culled increases, likely for 
Table 4. Estimated 10-yr average annual losses (US\$) due to Mycobacterium avium ssp. paratuberculosis infection for various dairy-producing regions assuming a mean herd-level prevalence of $50 \%$ and a mean withinherd prevalence of $10 \%$

\begin{tabular}{|c|c|c|c|c|c|c|}
\hline \multirow{2}{*}{$\frac{\text { Region }^{1}}{\text { EU-28 }}$} & \multicolumn{2}{|c|}{$\begin{array}{l}\text { Positive herds, losses } \\
\text { per cow }(90 \% \mathrm{CI})\end{array}$} & \multicolumn{2}{|c|}{$\begin{array}{l}\text { Positive herds, losses as \% } \\
\text { of milk revenue (90\% CI) }\end{array}$} & \multicolumn{2}{|c|}{$\begin{array}{l}\text { Regional losses in } \\
\text { millions }(90 \% \text { CI })\end{array}$} \\
\hline & 31.73 & $(21.86-42.28)$ & 1.08 & $(0.75-1.44)$ & 364.31 & $(205.91-551.59)$ \\
\hline $\mathrm{DEU}$ & 36.40 & $(25.19-47.83)$ & 1.11 & $(0.77-1.46)$ & 74.86 & $(42.13-113.37)$ \\
\hline FRA & 31.33 & $(21.71-41.59)$ & 1.11 & $(0.77-1.48)$ & 55.73 & $(31.71-83.60)$ \\
\hline GBR & 34.27 & $(23.66-45.46)$ & 1.06 & $(0.73-1.41)$ & 32.28 & $(18.24-48.74)$ \\
\hline POL & 20.77 & $(14.27-27.88)$ & 0.86 & $(0.59-1.15)$ & 23.05 & $(12.98-35.39)$ \\
\hline NLD & 42.82 & $(29.77-56.74)$ & 1.11 & $(0.77-1.47)$ & 33.31 & $(18.89-50.42)$ \\
\hline ITA & 33.06 & $(23.09-43.92)$ & 1.03 & $(0.72-1.37)$ & 28.08 & $(15.94-42.38)$ \\
\hline IRL & 37.36 & $(25.29-49.87)$ & 1.67 & $(1.13-2.22)$ & 25.65 & $(14.27-38.95)$ \\
\hline ESP & 30.76 & $(21.13-41.14)$ & 0.93 & $(0.64-1.25)$ & 12.61 & $(7.10-19.03)$ \\
\hline DNK & 47.53 & $(32.96-62.98)$ & 1.14 & $(0.79-1.51)$ & 13.57 & $(7.70-20.50)$ \\
\hline BEL & 33.64 & $(23.31-44.70)$ & 1.12 & $(0.78-1.49)$ & 8.92 & $(5.03-13.56)$ \\
\hline AUT & 33.54 & $(23.21-44.57)$ & 1.21 & $(0.84-1.60)$ & 8.96 & $(5.09-13.47)$ \\
\hline CZE & 30.33 & $(20.80-40.86)$ & 0.88 & $(0.60-1.18)$ & 5.46 & $(3.10-8.33)$ \\
\hline SWE & 40.89 & $(28.26-54.38)$ & 1.14 & $(0.78-1.51)$ & 6.42 & $(3.61-9.78)$ \\
\hline FIN & 44.10 & $(30.85-58.60)$ & 1.09 & $(0.76-1.44)$ & 5.84 & $(3.33-8.84)$ \\
\hline USA & 42.26 & $(29.09-56.00)$ & 1.12 & $(0.77-1.48)$ & 198.42 & $(112.42-300.44)$ \\
\hline $\mathrm{CA}$ & 41.73 & $(29.00-55.33)$ & 1.10 & $(0.76-1.46)$ & 36.29 & $(20.51-55.30)$ \\
\hline WI & 39.42 & $(27.19-52.44)$ & 1.01 & $(0.70-1.34)$ & 25.18 & $(14.26-38.06)$ \\
\hline ID & 37.23 & $(25.50-50.04)$ & 0.92 & $(0.63-1.24)$ & 11.37 & $(6.40-17.54)$ \\
\hline NY & 43.61 & $(30.35-57.84)$ & 1.12 & $(0.78-1.49)$ & 13.62 & $(7.83-20.61)$ \\
\hline $\mathrm{TX}$ & 40.69 & $(28.27-54.12)$ & 1.05 & $(0.73-1.39)$ & 10.97 & $(6.19-16.69)$ \\
\hline MI & 40.88 & $(28.06-54.44)$ & 0.95 & $(0.65-1.27)$ & 8.69 & $(4.91-13.14)$ \\
\hline $\mathrm{PA}$ & 36.40 & $(25.20-48.13)$ & 1.09 & $(0.75-1.44)$ & 9.47 & $(5.38-14.23)$ \\
\hline $\mathrm{MN}$ & 38.56 & $(26.68-51.19)$ & 1.09 & $(0.75-1.44)$ & 8.76 & $(4.95-13.26)$ \\
\hline NM & 38.82 & $(26.77-51.81)$ & 0.95 & $(0.66-1.27)$ & 6.42 & $(3.60-9.67)$ \\
\hline WA & 42.57 & $(29.54-56.43)$ & 1.08 & $(0.75-1.43)$ & 5.91 & $(3.36-8.96)$ \\
\hline BRA & 8.31 & $(5.78-11.02)$ & 1.01 & $(0.71-1.35)$ & 71.07 & $(40.35-107.28)$ \\
\hline CHN & 13.29 & $(9.17-17.83)$ & 0.96 & $(0.66-1.29)$ & 79.59 & $(45.14-120.88)$ \\
\hline RUS & 14.25 & $(9.73-19.11)$ & 0.87 & $(0.59-1.16)$ & 48.70 & $(27.68-75.12)$ \\
\hline NZL & 21.75 & $(15.05-28.85)$ & 1.37 & $(0.95-1.82)$ & 53.95 & $(30.52-81.69)$ \\
\hline TUR & 11.44 & $(7.85-15.39)$ & 0.90 & $(0.62-1.21)$ & 36.36 & $(20.61-55.29)$ \\
\hline CAN & 56.99 & $(39.35-75.72)$ & 1.00 & $(0.69-1.33)$ & 27.78 & $(15.60-42.04)$ \\
\hline $\mathrm{QC}$ & 53.30 & $(36.93-70.94)$ & 0.97 & $(0.67-1.29)$ & 9.47 & $(5.35-14.38)$ \\
\hline $\mathrm{ON}$ & 55.35 & $(38.36-73.56)$ & 1.01 & $(0.70-1.34)$ & 8.98 & $(5.09-13.6)$ \\
\hline $\mathrm{BC}$ & 62.94 & $(43.57-83.46)$ & 0.99 & $(0.69-1.31)$ & 2.65 & $(1.48-4.00)$ \\
\hline $\mathrm{AB}$ & 67.16 & $(46.36-89.14)$ & 1.09 & $(0.76-1.45)$ & 2.66 & $(1.51-4.04)$ \\
\hline MB & 56.64 & $(38.94-75.90)$ & 0.96 & $(0.66-1.29)$ & 1.17 & $(0.65-1.79)$ \\
\hline SK & 62.32 & $(43.15-82.92)$ & 1.03 & $(0.71-1.37)$ & 0.91 & $(0.52-1.39)$ \\
\hline NS & 52.26 & $(36.20-70.16)$ & 0.93 & $(0.64-1.25)$ & 0.56 & $(0.32-0.85)$ \\
\hline NB & 51.05 & $(35.08-68.36)$ & 0.95 & $(0.66-1.28)$ & 0.49 & $(0.28-0.75)$ \\
\hline $\mathrm{PE}$ & 52.63 & $(36.33-70.82)$ & 0.93 & $(0.64-1.25)$ & 0.38 & $(0.21-0.58)$ \\
\hline NL & 77.01 & $(53.31-102.24)$ & 1.01 & $(0.70-1.34)$ & 0.23 & $(0.13-0.35)$ \\
\hline AUS & 28.21 & $(19.51-37.61)$ & 1.38 & $(0.95-1.84)$ & 21.56 & $(12.19-32.84)$ \\
\hline JPN & 81.53 & $(56.37-108.24)$ & 1.02 & $(0.70-1.35)$ & 34.63 & $(19.45-52.64)$ \\
\hline
\end{tabular}

${ }^{1}$ EU-28 = European Union; DEU = Germany; FRA = France; GBR = Great Britain; POL = Poland; NLD $=$ the Netherlands; ITA $=$ Italy; IRL $=$ Ireland; ESP $=$ Spain; DNK $=$ Denmark; BEL = Belgium; AUT = Austria; $\mathrm{CZE}=$ Czechia; $\mathrm{SWE}=$ Sweden; FIN = Finland; USA = United States; CA = California; WI = Wisconsin; ID = Idaho; NY = New York; TX = Texas; MI = Michigan; PA = Pennsylvania; MN = Minnesota; $\mathrm{NM}=$ New Mexico; WA = Washington; BRA = Brazil; CHN = China; RUS = Russia; NZL = New Zealand; $\mathrm{TUR}=$ Turkey; $\mathrm{CAN}=$ Canada; $\mathrm{QC}=$ Québec; $\mathrm{ON}=$ Ontario; $\mathrm{BC}=$ British Columbia; $\mathrm{AB}=$ Alberta; $\mathrm{MB}$ $=$ Manitoba; SK = Saskatchewan; NS = Nova Scotia; PE = Prince Edward Island; NL = Newfoundland; AUS $=$ Australia; JPN = Japan.

reasons not explicitly attributable to JD but for belowaverage weight gain, reproductive issues and infertility, or increased susceptibility to other diseases, 2 things happen in the model: the infection pressure, or amount of MAP bacteria present in the herd, decreases, resulting in less severe infections among other animals, and second, the animals are removed before their infections can progress to the more costly stages, from both the health and economic perspectives. However, for premature culling losses, these indirect effects are outweighed by the direct effect of less overall culling, so the overall relationship is positive. It is also important to recognize that the net costs associated with a higher culling rate may be overestimated in this model. Because only the 
Table 5. Estimated 10-yr average annual losses (US\$) for Canadian dairy producers assuming a mean herd-level Mycobacterium avium ssp. paratuberculosis (MAP) prevalence of $50 \%$, a mean within-herd prevalence of $10 \%$, and with consideration for supply management (fixed output over time and production losses allocated as increased variable costs necessary to maintain production)

\begin{tabular}{|c|c|c|c|c|c|c|c|}
\hline \multirow{2}{*}{$\frac{\text { Region }^{1}}{\mathrm{CAN}}$} & \multirow{2}{*}{$\begin{array}{c}\begin{array}{c}\text { Variable costs } \\
\text { per } \operatorname{cow}^{2}(\text { US } \$)\end{array} \\
2,476\end{array}$} & \multicolumn{2}{|c|}{$\begin{array}{l}\text { Positive herds, losses } \\
\text { per cow }(90 \% \mathrm{CI})\end{array}$} & \multicolumn{2}{|c|}{$\begin{array}{c}\text { Positive herds, losses as \% } \\
\text { of milk revenue (90\% CI) }\end{array}$} & \multicolumn{2}{|c|}{$\begin{array}{c}\text { Regional losses } \\
\text { in millions }(90 \% \mathrm{CI})\end{array}$} \\
\hline & & 35.11 & $(24.34-46.18)$ & 0.62 & $(0.43-0.81)$ & 17.11 & $(9.67-25.74)$ \\
\hline $\mathrm{QC}$ & 2,430 & 32.23 & $(22.54-42.34)$ & 0.59 & $(0.41-0.77)$ & 5.73 & $(3.23-8.58)$ \\
\hline $\mathrm{BC}$ & 3,204 & 41.39 & $(28.87-53.94)$ & 0.65 & $(0.45-0.85)$ & 1.74 & $(0.98-2.62)$ \\
\hline $\mathrm{AB}$ & 3,106 & 46.42 & $(32.22-61.30)$ & 0.76 & $(0.53-1.00)$ & 1.84 & $(1.05-2.80)$ \\
\hline MB & 3,014 & 36.94 & $(25.82-48.50)$ & 0.63 & $(0.44-0.82)$ & 0.76 & $(0.44-1.15)$ \\
\hline NB & 2,464 & 31.28 & $(21.97-40.93)$ & 0.58 & $(0.41-0.76)$ & 0.30 & $(0.17-0.45)$ \\
\hline $\mathrm{PE}$ & 2,144 & 28.48 & $(19.84-37.38)$ & 0.50 & $(0.35-0.66)$ & 0.21 & $(0.12-0.31)$ \\
\hline NL & 4,112 & 53.16 & $(37.11-69.50)$ & 0.70 & $(0.49-0.91)$ & 0.16 & $(0.09-0.24)$ \\
\hline
\end{tabular}

${ }^{1} \mathrm{CAN}=$ Canada; $\mathrm{QC}=$ Québec ON = Ontario; $\mathrm{BC}=$ British Columbia; $\mathrm{AB}=$ Alberta $; \mathrm{MB}=$ Manitoba; $\mathrm{SK}=\mathrm{Saskatchewan} ; \mathrm{NS}=\mathrm{Nova}$ Scotia; PE = Prince Edward Island; NL = Newfoundland.

${ }^{2}$ STATCAN-Table 32-10-0136-01, farm operating revenues and expenses, annual (STATCAN, 2019b). Sum of "Feed, supplements, straw, and bedding," "Veterinary fees, medicine, and breeding fees," and "Salaries and wages, including benefits related to employee salaries" for average dairy farms across all revenue levels in 2018. Total per farm divided by number of cows per farm. Number of cows per farm obtained by number of cattle divided by number of farms: CDIC-Number of farms with shipments of milk (CDIC, 2019b). Number of cattle: STATCAN-Table 32-10-0130-01, number of cattle, by class and farm type (STATCAN, 2020).

economic impact of culling due to MAP infection was considered, this model ignores the potential benefits associated with having a greater proportion of younger animals in the herd. For example, age-related conditions such as reduced fertility, udder health, and foot health are all potential sources of economic losses that could be partially offset as a direct result of an increased cow-culling rate.

Last, we discuss the estimates for Canadian herds with consideration for supply management. Although the general method described is appropriate for most dairy industries, the Canadian industry requires special attention. Canada's dairy sector operates with planned and controlled domestic production levels, administered cost-of-production-based pricing of fluid milk, and import controls which help to insulate producers from competitive forces both domestic and foreign. There are 2 consequences relevant to this model: (1) production losses can no longer be measured as forgone milk sales due to the production quota system, and (2) Canada has an above-average farm-gate price, the highest among countries modeled (aside from Japan, which subsidizes dairy production at particularly high rates) and much higher than the farm-gate price in the United States, Canada's most comparable counterpart. Apart from a higher level of total annual output in the United States, both countries have similar dairy sector characteristics in terms of genetics, marketing, consumer preferences, and annual production per cow, and assuming the same within-herd and herd-level MAP prevalence across the 2 countries, there should be similar estimated losses per cow due to MAP infection. However, the above-average farm-gate price in Canada results in a greater valuation of production losses and therefore total losses per cow in Canada, but those losses represent a lower percentage of gross milk revenue. Although these differences are attributable in part to varying technical and allocative efficiencies across dairy sectors, which are not addressed by this study, the effects of the differing market structures are addressed; to reflect the constraint of fixed production levels in Canada, production losses were subsequently re-estimated as the cost of having additional, less productive MAP-positive cows to maintain a fixed level of production over the 10-yr horizon. Once adjusted, estimated annual losses per cow within MAP-infected herds in Canada fell from US\$56.99 to US\$35.11. Although this is more in line with estimated losses of US $\$ 42.26$ per cow in the United Sates, as a percentage of gross milk revenue, Canadian losses fell from $1.00 \%$ to $0.62 \%$ compared with $1.12 \%$ in the United States. This may be an overcorrection. Although overall production and farm-gate prices in Canada are set annually by the Canadian Dairy Commission and producers can only sell the amount of milk for which they have production quota, there is still competition among producers. The overall level of production generally increases year over year (CDIC, 2019a) and producers trade quota among themselves; more profitable producers purchase quota from less profitable ones through a quota exchange market to increase the size of their operations. The number of dairy farms in Canada has steadily decreased over the last several decades while the size of herds has increased (CDIC, 2019b). In other words, producers operate in an environment somewhere in between fixed production and a purely competitive 
market, and therefore true losses due to MAP infection in infected Canadian dairy herds likely lie somewhere in between the 2 estimates, or between US $\$ 35.11$ and US $\$ 56.99$ per cow per year.

Although the estimated losses due to JD in major dairy-producing regions are significant, they are likely much less than the losses associated with more easily addressable herd health issues such as mastitis. It may seem intuitive that healthier dairy herds generate more profits for producers, but dairy production is complex and producers are often forced to prioritize short-term, immediate losses from relatively acute diseases such as mastitis over long-term losses from chronic diseases such as JD. However, if left unchecked, JD will continue to spread, losses will continue to increase, and controlling the disease will become increasingly difficult. It is also important to recognize that research into potential interactions between MAP and other pathogens that affect dairy cows is still developing. For example, higher mastitis incidences (Diéguez et al., 2008) and higher culling rates due to clinical mastitis (Arrazuría et al., 2014) have been observed in MAP-positive herds, and MAP-positive cows have been shown to have a higher incidence of clinical mastitis (Rossi et al., 2017). National control programs have already been established in several countries including Australia, Ireland, Japan, the Netherlands, and the United States, and JD is listed by the World Organisation for Animal Health as a priority disease for international trade. The dairy herd-level MAP prevalence in Canada has recently been estimated to be $42 \%$ (Corbett et al., 2018), yet Canada has no mandatory control program in place despite JD's pervasiveness. MAP infection in dairy herds may also pose a public health threat; there is concern that MAP may be associated with Crohn's disease in humans (El-Zaatari et al., 2001; Harris and Lammerding, 2001; Hermon-Taylor, 2001; Chacon et al., 2004; Naser et al., 2004; Feller et al., 2007; Abubakar et al., 2008; Waddell et al., 2015), infected cows can shed live MAP in both their feces and milk, and live MAP have been recovered from pasteurized milk (Ellingson et al., 2005; Shankar et al., 2010).

\section{CONCLUSIONS}

Although the economic impact of JD in dairy herds has been estimated before, this study is unique in 2 ways: first, it estimates economic losses due to JD across a comprehensive selection of major dairy-producing regions within one methodological framework, and second, it attempts to capture the relationship between economic losses due to JD and the market conditions that arise as a result of supply management in Canada. With assumptions of $10 \%$ within-herd prevalence, $50 \%$
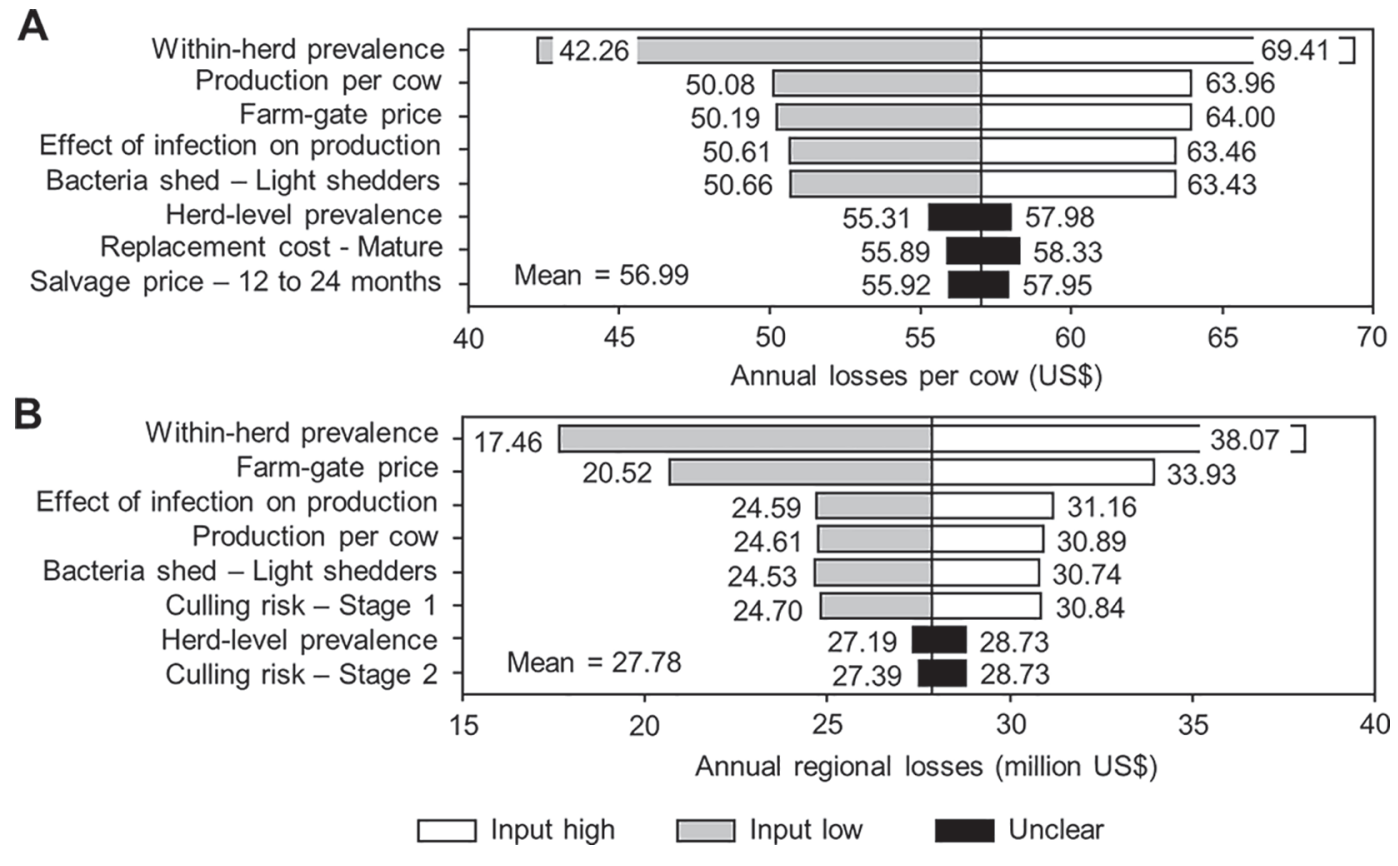

Figure 4. Sensitivity of estimated losses due to Mycobacterium avium ssp. paratuberculosis (MAP) infection in Canadian dairy herds to a range of input variables (10,000 iterations) assuming initial mean values of $10 \%$ within-herd prevalence and $50 \%$ herd-level prevalence. The color of the sensitivity bars indicates the direction of the relationship between the variable and estimated losses (gray indicates the effect of variable values below their mean value, white indicates the effect of values above their mean, and black indicates that the effect is unclear). (A) Total annual losses per cow. (B) Annual regional losses. 


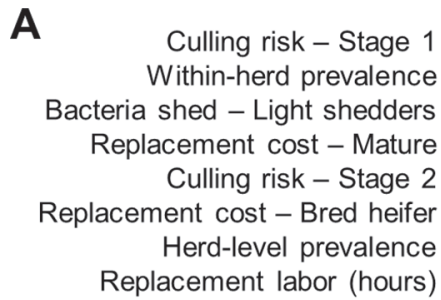

B

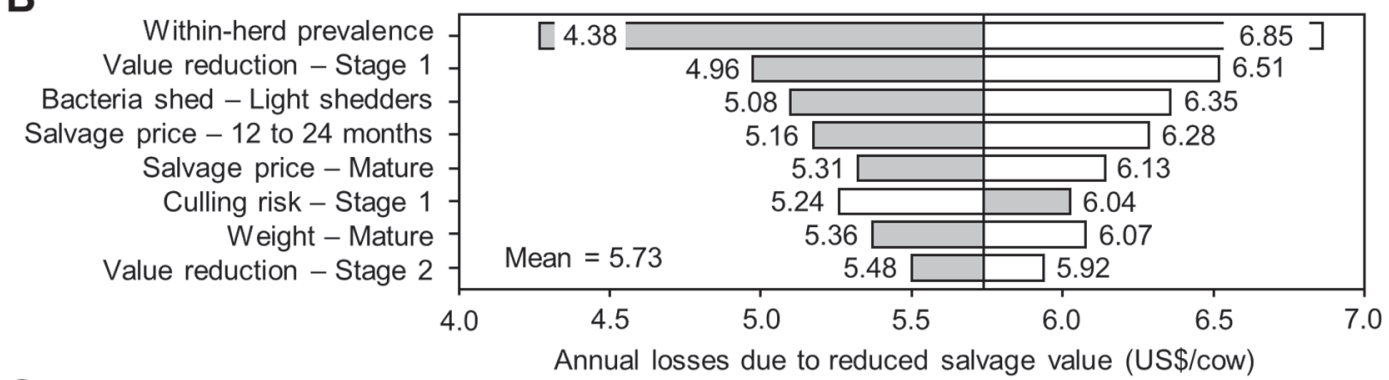

C

Figure 5. Sensitivity of estimated sources of losses due to Mycobacterium avium ssp. paratuberculosis (MAP) infection in Canadian dairy herds to a range of input variables (10,000 iterations) assuming initial mean values of $10 \%$ within-herd prevalence and $50 \%$ herd-level prevalence. The color of the sensitivity bars indicates the direction of the relationship between the variable and estimated losses (gray indicates the effect of variable values below their mean value, white indicates the effect of values above their mean, and black indicates that the effect is unclear). (A) Annual losses due to premature culling. (B) Annual losses due to reduced salvage value. (C) Annual losses due to reduced production.

herd-level prevalence, and a doubling of within-herd prevalence over $10 \mathrm{yr}$, an estimated $1 \%$ of gross milk revenue is lost annually in MAP-positive dairy herds. This translates to revenue-weighted average losses of US $\$ 33$ per cow per year on infected farms, with greater losses in regions with higher farm-gate prices and production per cow. Twenty-four percent of those losses are attributable to premature culling, $11 \%$ are attributable to reduced salvage values, and $65 \%$ are attributable to reduced production. Each year, an estimated US\$198 million is lost due to JD in the United States, US\$75 million in Germany, US\$56 million in France, US $\$ 54$ million in New Zealand, and between US $\$ 17$ million and US $\$ 28$ million in Canada, one of the smallest dairy-producing regions modeled. As research into MAP infection in dairy herds continues to expand, the input values used in these models can be adjusted and updated, perhaps providing evidence of an even greater direct economic incentive for producers to control this disease and for the continued development of new testing methods and pharmaceutical interventions such as vaccines. This research is an important contribution to the policy discussion surrounding paratuberculosis control in Canada and internationally.

\section{ACKNOWLEDGMENTS}

This research benefited from discussions with Jeroen De Buck, Karin Orsel, and Paul Burden from the University of Calgary, Departments of Production Animal Health and Ecosystem and Public Health, and Joseph Rasmussen from the University of Lethbridge, Department of Biological Sciences. This research was supported by Genome Canada, Genome Prairie, and Genome British Columbia (225RVA). The authors have not stated any conflicts of interest. 


\section{REFERENCES}

Abubakar, I., D. Myhill, S. H. Aliyu, and P. R. Hunter. 2008. Detection of Mycobacterium avium subspecies paratuberculosis from patients with Crohn's disease using nucleic acid-based techniques: A systematic review and meta-analysis. Inflamm. Bowel Dis. 14:401-410.

Arrazuría, R., I. Arnaiz, R. Fouz, C. Calvo, C. Eiras, and F. J. Diéguez. 2014. Association between Mycobacterium avium ssp. paratuberculosis infection and culling in dairy cattle herds. Arch. Med. Vet. 46:39-44.

Barkema, H. W., K. Orsel, S. S. Nielsen, A. P. Koets, V. P. M. G. Rutten, J. P. Bannantine, G. P. Keefe, D. F. Kelton, S. J. Wells, R. J. Whittington, C. G. Mackintosh, E. J. Manning, M. F. Weber, C. Heuer, T. L. Forde, C. Ritter, S. Roche, C. S. Corbett, R. Wolf, P. J. Griebel, J. P. Kastelic, and J. De Buck. 2018. Knowledge gaps that hamper prevention and control of Mycobacterium avium subspecies paratuberculosis infection. Transbound. Emerg. Dis. 65:125-148.

BEA. 2019. Regional Economic Accounts - SAGDP Tables: Annual GDP by State. Accessed Jan. 13, 2020. https://www.bea.gov/ data/gdp/gdp-state.

Beard, P. M., M. J. Daniels, D. Henderson, A. Pirie, K. Rudge, D. Buxton, S. Rhind, A. Greig, M. R. Hutchings, I. McKendrick, K. Stevenson, and J. M. Sharp. 2001. Paratuberculosis infection of nonruminant wildlife in Scotland. J. Clin. Microbiol. 39:1517-1521.

Benedictus, G., A. A. Dijkhuizen, and J. Stelwagen. 1985. (Economic losses to farms due to paratuberculosis in cattle). Tijdschr. Diergeneeskd. 110:310-319.

Bhattarai, B., G. T. Fosgate, J. B. Osterstock, C. P. Fossler, S. C. Park, and A. J. Roussel. 2013. Perceptions of veterinarians in bovine practice and producers with beef cow-calf operations enrolled in the US Voluntary Bovine Johne's Disease Control Program concerning economic losses associated with Johne's disease. Prev. Vet. Med. 112:330-337.

Boelaert, F., K. Walravens, P. Biront, J. P. Vermeersch, D. Berkvens, and J. Godfroid. 2000. Prevalence of paratuberculosis (Johne's disease) in the Belgian cattle population. Vet. Microbiol. 77:269-281.

Bolton, M. W., R. B. Pillars, J. B. Kaneene, W. A. Mauer, and D. L. Grooms. 2011. Detection of Mycobacterium avium subspecies paratuberculosis in naturally exposed dairy heifers and associated risk factors. J. Dairy Sci. 94:4669-4675.

CDIC. 2019a. D037-3 - Average Production by Province. Accessed Oct. 10, 2019. https://aimis-simia-cdic-ccil.agr.gc.ca/rp/index-eng .cfm?action $=\mathrm{pR} \& \mathrm{r}=215 \& \mathrm{pdctc}=$.

CDIC. 2019b. D056 - Number of Farms with Shipments of Milk by Province. Accessed Oct. 10, 2019. https://aimis-simia-cdic-ccil.agr .gc.ca/rp/index-eng.cfm?action $=$ pR\&r $=220 \& p d c t c=$.

CDIC. 2019c. MI011 - Canadian farm cash receipts from dairying. Accessed Sep. 14, 2020. https://aimis-simia-cdic-ccil.agr.gc.ca/rp/ index-eng. $c f m ?$ action $=p R \& r=272 \& p d c t c=$.

Chacon, O., L. E. Bermudez, and R. G. Barletta. 2004. Johne's disease, inflammatory bowel disease, and Mycobacterium paratuberculosis. Annu. Rev. Microbiol. 58:329-363.

CLAL. 2019. Dairy Sector by Country. Accessed Sep. 15, 2020. https: //www.clal.it/en/.

Collins, M. T., D. C. Sockett, W. J. Goodger, T. A. Conrad, C. B. Thomas, and D. J. Carr. 1994. Herd prevalence and geographic distribution of, and risk factors for, bovine paratuberculosis in Wisconsin. J. Am. Vet. Med. Assoc. 204:636-641.

Corbett, C. S., S. A. Naqvi, C. A. Bauman, J. De Buck, K. Orsel, F. Uehlinger, D. F. Kelton, and H. W. Barkema. 2018. Prevalence of Mycobacterium avium ssp. paratuberculosis infections in Canadian dairy herds. J. Dairy Sci. 101:11218-11228.

Crossley, B. M., F. J. Zagmutt-Vergara, T. L. Fyock, R. H. Whitlock, and I. A. Gardner. 2005. Fecal shedding of Mycobacterium avium ssp. paratuberculosis by dairy cows. Vet. Microbiol. 107:257-263.

Dairy Australia. 2019. Dairy in Focus - 2018. Accessed Jan. 26, 2020. https://www.dairyaustralia.com.au/ publications/australian-dairy-industry-in-focus-2018?id= B81A5CE26AAE4C0F898E8F3BFF0014D9.
Diéguez, F. J., I. Arnaiz, M. L. Sanjuán, M. J. Vilar, M. López, and E. Yus. 2007. Prevalence of serum antibodies to Mycobacterium avium ssp. paratuberculosis in cattle in Galicia (northwest Spain). Prev. Vet. Med. 82:321-326.

Diéguez, F. J., I. Arnaiz, M. L. Sanjuán, M. J. Vilar, and E. Yus. 2008. Management practices associated with Mycobacterium avium subspecies paratuberculosis infection and the effects of the infection on dairy herds. Vet. Rec. 162:614-617.

Donaghy, J., M. Keyser, J. Johnston, F. P. Cilliers, P. A. Gouws, and M. T. Rowe. 2009. Inactivation of Mycobacterium avium ssp. paratuberculosis in milk by UV treatment. Lett. Appl. Microbiol. 49:217-221.

El-Zaatari, F. A. K., M. S. Osato, and D. Y. Graham. 2001. Etiology of Crohn's disease: The role of Mycobacterium avium paratuberculosis. Trends Mol. Med. 7:247-252.

Ellingson, J. L. E., J. L. Anderson, J. J. Koziczkowski, R. P. Radcliff, S. J. Sloan, S. E. Allen, and N. M. Sullivan. 2005. Detection of viable Mycobacterium avium ssp. paratuberculosis in retail pasteurized whole milk by two culture methods and PCR. J. Food Prot. 68:966-972.

Fecteau, M. E., and R. H. Whitlock. 2010. Paratuberculosis in cattle. Pages 144-156 in Paratuberculosis: Organism, Disease, Control. M. A. Behr and D. M. Collins, ed. CABI, Wallingford, UK.

Fecteau, M.-E., R. H. Whitlock, C. D. Buergelt, and R. W. Sweeney. 2010. Exposure of young dairy cattle to Mycobacterium avium ssp. paratuberculosis (MAP) through intensive grazing of contaminated pastures in a herd positive for Johne's disease. Can. Vet. J. 51:198-200.

Feller, M., K. Huwiler, R. Stephan, E. Altpeter, A. Shang, H. Furrer, G. E. Pfyffer, T. Jemmi, A. Baumgartner, and M. Egger. 2007. Mycobacterium avium subspecies paratuberculosis and Crohn's disease: a systematic review and meta-analysis. Lancet Infect. Dis. 7:607-613.

Garcia, A. B., and L. Shalloo. 2015. Invited review: The economic impact and control of paratuberculosis in cattle. J. Dairy Sci. 98:5019-5039.

Gasteiner, J., H. Wenzl, K. Fuchs, U. Jark, and W. Baumgartner. 1999. Serological cross-sectional study of paratuberculosis in cattle in Austria. J. Vet. Med. B Infect. Dis. Vet. Public Health 46:457466.

Good, M., T. Clegg, H. Sheridan, D. Yearsely, T. O'Brien, J. Egan, and P. Mullowney. 2009. Prevalence and distribution of paratuberculosis (Johne's disease) in cattle herds in Ireland. Ir. Vet. J. 62:597-606.

Greig, A., K. Stevenson, D. Henderson, V. Perez, V. Hughes, I. Pavlik, M. E. Hines, I. McKendrick, and J. M. Sharp. 1999. Epidemiological study of paratuberculosis in wild rabbits in Scotland. J. Clin. Microbiol. 37:1746-1751.

Groenendaal, H., M. Nielen, A. W. Jalvingh, S. H. Horst, D. T. Galligan, and J. W. Hesselink. 2002. A simulation of Johne's disease control. Prev. Vet. Med. 54:225-245

Hacker, U., K. Hüttner, and M. Konow. 2004. (Investigation of serological prevalence and risk factors of paratuberculosis in dairy farms in the state of Mecklenburg-Westpommerania, Germany). Berl. Munch. Tierarztl. 117:140-144.

Harris, J. E., and A. M. Lammerding. 2001. Crohn's disease and Mycobacterium avium ssp. paratuberculosis: Current issues. J. Food Prot. 64:2103-2110.

Hendrick, S. H., D. F. Kelton, K. E. Leslie, K. D. Lissemore, M. Archambault, and T. F. Duffield. 2005. Effect of paratuberculosis on culling, milk production, and milk quality in dairy herds. J. Am. Vet. Med. Assoc. 227:1302-1308. https://doi.org/10.2460/javma .2005.227.1302.

Hermon-Taylor, J. 2001. Mycobacterium avium subspecies paratuberculosis is a cause of Crohn's disease. Gut 49:755-757. https://doi .org/10.1136/gut.49.6.755.

IRS. 2020. Yearly average currency exchange rates. Accessed Jan. 13 2020. https://www.irs.gov/individuals/international-taxpayers/ yearly-average-currency-exchange-rates. 
Johnson-Ifearulundu, Y., J. B. Kaneene, and J. W. Lloyd. 1999. Herdlevel economic analysis of the impact of paratuberculosis on dairy herds. J. Am. Vet. Med. Assoc. 214:822-825.

Jones, C. M., and J. Heinrichs. 2017. Growth Charts for Dairy Heifers: Comparing to a breed standard can indicate if heifer growth is progressing normally. Accessed Jan. 17, 2020. https://extension .psu.edu/growth-charts-for-dairy-heifers.

Jubb, T. F., and J. W. Galvin. 2004. Effect of a test and control program for bovine Johne's disease in Victorian dairy herds 1992 - 2002. Aust. Vet. J. 82:228-232. https://doi.org/10.1111/j.1751 -0813.2004.tb12685.x.

Jubb, T. F., E. S. G. Sergeant, A. P. L. Callinan, and J. W. Galvin. 2004. Estimate of the sensitivity of an ELISA used to detect Johne's disease in Victorian dairy cattle herds. Aust. Vet. J. 82:569-573. https://doi.org/10.1111/j.1751-0813.2004.tb11206.x.

Kennedy, D. J., and L. Citer. 2010. Paratuberculosis control measures in Australia. Pages 330-343 in Paratuberculosis: Organism, Disease, Control. M. A. Behr and D. M. Collins, ed. CABI, Wallingford, UK

Kudahl, A. B., and S. S. Nielsen. 2009. Effect of paratuberculosis on slaughter weight and slaughter value of dairy cows. J. Dairy Sci. 92:4340-4346. https://doi.org/10.3168/jds.2009-2039.

Lombard, J. E., F. B. Garry, B. J. McCluskey, and B. A. Wagner. 2005. Risk of removal and effects on milk production associated with paratuberculosis status in dairy cows. J. Am. Vet. Med. Assoc. 227:1975-1981. https://doi.org/10.2460/javma.2005.227.1975.

Macrotrends. 2020. S\&P 500 Historical Annual Returns. Accessed May 21, 2020. https://www.macrotrends.net/2526/sp-500-historical -annual-returns.

Manning, E. J., and M. T. Collins. 2001. Mycobacterium avium ssp. paratuberculosis: Pathogen, pathogenesis and diagnosis. Rev. Sci. Tech. 20:133-150.

Marquetoux, N., R. Mitchell, A. Ridler, C. Heuer, and P. Wilson. 2018. A synthesis of the patho-physiology of Mycobacterium avium subspecies paratuberculosis infection in sheep to inform mathematical modelling of ovine paratuberculosis. Vet. Res. (Faisalabad) 49:27. https://doi.org/10.1186/s13567-018-0522-1.

McAloon, C. G., P. Whyte, S. J. More, M. J. Green, L. O'Grady, A. Garcia, and M. L. Doherty. 2016. The effect of paratuberculosis on milk yield-A systematic review and meta-analysis. J. Dairy Sci. 99:1449-1460. https://doi.org/10.3168/jds.2015-10156.

McClure, H. M., R. J. Chiodini, D. C. Anderson, R. B. Swenson, W. R. Thayer, and J. A. Coutu. 1987. Mycobacterium paratuberculosis Infection in a colony of stumptail macaques (Macaca arctoides). J. Infect. Dis. 155:1011-1019. https://doi.org/10.1093/infdis/155 .5 .1011

McGregor, H., N. K. Dhand, O. P. Dhungyel, and R. J. Whittington. 2012. Transmission of Mycobacterium avium ssp. paratuberculosis: Dose-response and age-based susceptibility in a sheep model. Prev. Vet. Med. 107:76-84. https://doi.org/10.1016/j.prevetmed 2012.05.014

Mitchell, R. M., G. F. Medley, M. T. Collins, and Y. H. Schukken. 2012. A meta-analysis of the effect of dose and age at exposure on shedding of Mycobacterium avium subspecies paratuberculosis (MAP) in experimentally infected calves and cows. Epidemiol. Infect. 140:231-246. https://doi.org/10.1017/S0950268811000689.

Mortier, R. A. R., H. W. Barkema, J. M. Bystrom, O. Illanes, K. Orsel, R. Wolf, G. Atkins, and J. De Buck. 2013. Evaluation of age-dependent susceptibility in calves infected with two doses of Mycobacterium avium subspecies paratuberculosis using pathology and tissue culture. Vet. Res. (Faisalabad) 44:94. https://doi.org/ 10.1186/1297-9716-44-94.

Mortier, R. A. R., H. W. Barkema, K. Orsel, R. Wolf, and J. De Buck. 2014. Shedding patterns of dairy calves experimentally infected with Mycobacterium avium subspecies paratuberculosis. Vet. Res. (Faisalabad) 45:71. https://doi.org/10.1186/s13567-014-0071-1.

Muskens, J., H. W. Barkema, E. Russchen, K. van Maanen, Y. H. Schukken, and D. Bakker. 2000. Prevalence and regional distribution of paratuberculosis in dairy herds in the Netherlands. Vet. Microbiol. 77:253-261. https://doi.org/10.1016/S0378-1135(00)00310 -2 .
Naser, S. A., G. Ghobrial, C. Romero, and J. F. Valentine. 2004. Culture of Mycobacterium avium subspecies paratuberculosis from the blood of patients with Crohn's disease. Lancet 364:1039-1044. https://doi.org/10.1016/S0140-6736(04)17058-X.

OMAFRA. 2020. Culling Decisions: Dairy Cows. Accessed Sep. 13 , 2020. http://www.omafra.gov.on.ca/english/livestock/dairy/facts/ cullcowwelfare.htm\#: : text=Trends\%20in\%20culling\%20and\%20 markets,low $\% 20$ milk\%20production $\% 20(16 \% 25)$.

Ott, S. L., S. J. Wells, and B. A. Wagner. 1999. Herd-level economic losses associated with Johne's disease on US dairy operations. Prev. Vet. Med. 40:179-192. https://doi.org/10.1016/S0167 $-5877(99) 00037-9$.

Pillars, R. B., D. L. Grooms, C. A. Wolf, and J. B. Kaneene. 2009. Economic evaluation of Johne's disease control programs implemented on six Michigan dairy farms. Prev. Vet. Med. 90:223-232. https://doi.org/10.1016/j.prevetmed.2009.04.009.

Pozzato, N., K. Capello, A. Comin, N. Toft, S. S. Nielsen, G. Vicenzoni, and N. Arrigoni. 2011. Prevalence of paratuberculosis infection in dairy cattle in Northern Italy. Prev. Vet. Med. 102:83-86. https://doi.org/10.1016/j.prevetmed.2011.07.001.

Raizman, E. A., J. P. Fetrow, and S. J. Wells. 2009. Loss of income from cows shedding Mycobacterium avium subspecies paratuberculosis prior to calving compared with cows not shedding the organism on two Minnesota dairy farms. J. Dairy Sci. 92:4929-4936. https://doi.org/10.3168/jds.2009-2133.

Rossi, G., Y. T. Grohn, Y. H. Schukken, and R. L. Smith. 2017. The effect of Mycobacterium avium ssp. paratuberculosis infection on clinical mastitis occurrence in dairy cows. J. Dairy Sci. 100:74467454. https://doi.org/10.3168/jds.2017-12721.

Shankar, H., S. V. Singh, P. K. Singh, A. V. Singh, J. S. Sohal, and R. J. Greenstein. 2010. Presence, characterization, and genotype profiles of Mycobacterium avium subspecies paratuberculosis from unpasteurized individual and pooled milk, commercial pasteurized milk, and milk products in India by culture, PCR, and PCRREA methods. Int. J. Infect. Dis. 14:e121-e126. https://doi.org/ 10.1016/j.ijid.2009.03.031.

Shephard, R. W., S. H. Williams, and S. D. Beckett. 2016. Farm economic impacts of bovine Johne's disease in endemically infected Australian dairy herds. Aust. Vet. J. 94:232-239. https://doi.org/ 10.1111/avj.12455.

STATCAN. 2019a. Table 32-10-0077-01 Farm product prices, crops and livestock. Accessed Jan. 20, 2020. https://www150.statcan.gc .ca/t1/tbl1/en/tv.action?pid=3210007701.

STATCAN. 2019b. Table 32-10-0136-01 Farm operating revenues and expenses, annual. Accessed Sep. 16, 2020. https://www150.statcan .gc.ca/t1/tbl1/en/tv.action?pid=3210013601.

STATCAN. 2019c. Table 36-10-0222-01 Gross domestic product, expenditure-based, provincial and territorial, annual (x 1,000,000). Accessed Jan. 14, 2020. https://www150.statcan.gc.ca/t1/tbl1/ en/tv.action?pid $=3610022201$.

STATCAN. 2020. Table 32-10-0130-01 Number of cattle, by class and farm type (x 1,000). Accessed Sep. 13, 2020. https://www150 .statcan.gc.ca/t1/tbl1/en/tv.action?pid $=3210013001$.

Suwandi, A., I. Bargen, M. C. Pils, M. Krey, S. Zur Lage, A. K. Singh, T. Basler, C. S. Falk, U. Seidler, M. W. Hornef, R. Goethe, and S. Weiss. 2017. CD4 T Cell dependent colitis exacerbation following re-exposure of Mycobacterium avium ssp. paratuberculosis. Front. Cell. Infect. Microbiol. 7:75. https://doi.org/10.3389/fcimb.2017 .00075 .

Tiwari, A. 2005. Seroprevalence, production impacts, economics and risk factors of Mycobacterium avium subspecies paratuberculosis in Canadian dairy cattle. Page 349 in Health Management. Atlantic Veterinary College, University of Prince Edward Island, PE, Canada.

Tiwari, A., J. A. VanLeeuwen, I. R. Dohoo, G. P. Keefe, and A. Weersink. 2008. Estimate of the direct production losses in Canadian dairy herds with subclinical Mycobacterium avium subspecies paratuberculosis infection. Can. Vet. J. 49:569-576.

Tiwari, A., J. A. VanLeeuwen, S. L. B. McKenna, G. P. Keefe, and H. W. Barkema. 2006. Johne's disease in Canada Part I: clini- 
cal symptoms, pathophysiology, diagnosis, and prevalence in dairy herds. Can. Vet. J. 47:874-882.

Treasury Board of Canada. 2007. Canadian Cost-Benefit Analysis Guide: Regulatory Proposals. Accessed May 21, 2020. https:// www.tbs-sct.gc.ca/rtrap-parfa/analys/analys-eng.pdf.

USDA. 2020. National Dairy Comprehensive Report - Monthly 02/29/2020. Accessed Feb. 11, 2020. https://www.ams.usda.gov/ mnreports/lsmdairycomp.pdf.

USDA ERS. 2019. Dairy data - milk and cow production by State and region. Accessed Jan. 14, 2020. https://www.ers.usda.gov/ webdocs/DataFiles/48685/milkcowsandprod_1_.xlsx?v=2695.

USDA NASS. 2019. Farm Labor - 05/30/2019. Accessed Jan. 19, 2020. https://www.nass.usda.gov/Publications/Todays_Reports/ reports/fmla0519.pdf.

Van Biert, P. 2019. Economics of Milk Production in Alberta, 2018: The Dairy Cost Study. Accessed Sep. 14, 2020. https://open .alberta.ca/dataset/abca66b6-d117-4ee2-8615-248fcb53262c/ resource/b43613f3-6128-407e-aa85-b7504e0f0907/download/ economics-of-milk-production-2018.pdf.

VanLeeuwen, J. A., L. Forsythe, A. Tiwari, and R. Chartier. 2005. Seroprevalence of antibodies against bovine leukemia virus, bovine viral diarrhea virus, Mycobacterium avium subspecies paratuberculosis, and Neospora caninum in dairy cattle in Saskatchewan. Can. Vet. J. 46:56-58.

VanLeeuwen, J. A., G. P. Keefe, R. Tremblay, C. Power, and J. J. Wichtel. 2001. Seroprevalence of infection with Mycobacterium avium subspecies paratuberculosis, bovine leukemia virus, and bovine viral diarrhea virus in Maritime Canada dairy cattle. Can. Vet. J. 42:193-198.

VanLeeuwen, J. A., A. Tiwari, J. C. Plaizier, and T. L. Whiting. 2006. Seroprevalences of antibodies against bovine leukemia virus, bovine viral diarrhea virus, Mycobacterium avium subspecies paratuberculosis, and Neospora caninum in beef and dairy cattle in Manitoba. Can. Vet. J. 47:783-786.

Waddell, L. A., A. Rajić, K. D. Stärk, and E. S. McEwen. 2015. The zoonotic potential of Mycobacterium avium ssp. paratuberculosis: a systematic review and meta-analyses of the evidence. Epidemiol. Infect. 143:3135-3157. https://doi.org/10.1017/S095026881500076X.
Weber, M. F., J. Kogut, J. de Bree, G. van Schaik, and M. Nielen. 2010. Age at which dairy cattle become Mycobacterium avium ssp. paratuberculosis faecal culture positive. Prev. Vet. Med. 97:29-36. https://doi.org/10.1016/j.prevetmed.2010.07.004.

Wells, S. J., and B. A. Wagner. 2000. Herd-level risk factors for infection with Mycobacterium paratuberculosis in US dairies and association between familiarity of the herd manager with the disease or prior diagnosis of the disease in that herd and use of preventive measures. J. Am. Vet. Med. Assoc. 216:1450-1457. https://doi .org/10.2460/javma.2000.216.1450.

Whitlock, R. H., S. J. Wells, R. W. Sweeney, and J. Van Tiem. 2000. ELISA and fecal culture for paratuberculosis (Johne's disease): Sensitivity and specificity of each method. Vet. Microbiol. 77:387398. https://doi.org/10.1016/S0378-1135(00)00324-2.

Whittington, R. J., D. J. Marshall, P. J. Nicholls, I. B. Marsh, and L. A. Reddacliff. 2004. Survival and dormancy of Mycobacterium avium ssp. paratuberculosis in the environment. Appl. Environ. Microbiol. 70:2989-3004. https://doi.org/10.1128/AEM.70.5.2989 -3004.2004 .

Windsor, P. A., and R. J. Whittington. 2010. Evidence for age susceptibility of cattle to Johne's disease. Vet. J. 184:37-44. https://doi .org/10.1016/j.tvjl.2009.01.007.

Wolf, R., K. Orsel, J. De Buck, and H. W. Barkema. 2015. Calves shedding Mycobacterium avium subspecies paratuberculosis are common on infected dairy farms. Vet. Res. (Faisalabad) 46:71. https://doi.org/10.1186/s13567-015-0192-1.

Woodbine, K. A., Y. H. Schukken, L. E. Green, A. Ramirez-Villaescusa, S. Mason, S. J. Moore, C. Bilbao, N. Swann, and G. F. Medley. 2009. Seroprevalence and epidemiological characteristics of Mycobacterium avium ssp. paratuberculosis on 114 cattle farms in south west England. Prev. Vet. Med. 89:102-109. https://doi .org/10.1016/j.prevetmed.2009.02.005.

World Bank. 2020. GDP per capita (current US\$). Accessed Jan. 4, 2020. https://data.worldbank.org/indicator/NY.GDP.PCAP.CD.

Zwick, L. S., T. F. Walsh, R. Barbiers, M. T. Collins, M. J. Kinsel, and R. D. Murnane. 2002. Paratuberculosis in a Mandrill (Papio sphinx). J. Vet. Diagn. Invest. 14:326-328. https://doi.org/10 $.1177 / 104063870201400409$ 


\section{APPENDIX}

Table A1. Key dairy sector characteristics for various dairy-producing regions in order of decreasing 2018 annual production

\begin{tabular}{|c|c|c|c|c|}
\hline Region $^{1}$ & $\begin{array}{l}\text { Annual production }{ }^{2} \\
(1,000 \mathrm{Mt})\end{array}$ & $\begin{array}{l}\text { Annual production } \\
(\mathrm{kg} / \mathrm{cow})\end{array}$ & $\begin{array}{l}\text { Dairy cattle }{ }^{4} \\
(1,000 \text { head })\end{array}$ & $\begin{array}{l}\text { Farm-gate price }{ }^{5} \\
(\mathrm{US} \$ / 100 \mathrm{~kg})\end{array}$ \\
\hline EU-28 & 166,744 & 7,279 & 22,906 & 40.22 \\
\hline DEU & 33,087 & 8,068 & 4,101 & 40.53 \\
\hline FRA & 25,055 & 7,058 & 3,550 & 39.92 \\
\hline GBR & 15,488 & 8,243 & 1,879 & 39.07 \\
\hline POL & 14,171 & 6,401 & 2,214 & 37.71 \\
\hline NLD & 14,090 & 9,079 & 1,552 & 42.50 \\
\hline ITA & 12,340 & 7,289 & 1,693 & 44.08 \\
\hline IRL & 7,831 & 5,720 & 1,369 & 39.20 \\
\hline ESP & 7,336 & 8,968 & 818 & 36.83 \\
\hline DNK & 5,615 & 9,851 & 570 & 42.41 \\
\hline BEL & 4,178 & 7,898 & 529 & 37.96 \\
\hline AUT & 3,821 & 7,169 & 533 & 38.77 \\
\hline CZE & 3,162 & 8,808 & 359 & 39.33 \\
\hline SWE & 2,760 & 8,818 & 313 & 40.85 \\
\hline FIN & 2,398 & 9,083 & 264 & 44.72 \\
\hline USA & 98,688 & 10,546 & 9,358 & 35.86 \\
\hline $\mathrm{CA}$ & 18,331 & 10,572 & 1,734 & 35.86 \\
\hline WI & 13,870 & 10,887 & 1,274 & 35.86 \\
\hline ID & 6,871 & 11,283 & 609 & 35.86 \\
\hline NY & 6,750 & 10,835 & 623 & 35.86 \\
\hline TX & 5,830 & 10,856 & 537 & 35.86 \\
\hline MI & 5,066 & 11,947 & 424 & 35.86 \\
\hline PA & 4,838 & 9,321 & 519 & 35.86 \\
\hline MN & 4,476 & 9,881 & 453 & 35.86 \\
\hline NM & 3,758 & 11,388 & 330 & 35.86 \\
\hline WA & 3,055 & 11,030 & 277 & 35.86 \\
\hline BRA & 33,491 & 1,963 & 17,060 & 41.71 \\
\hline $\mathrm{CHN}^{6}$ & 30,640 & 2,563 & 11,955 & 53.87 \\
\hline RUS & 30,611 & 4,492 & 6,815 & 36.58 \\
\hline NZL & 21,947 & 4,437 & 4,946 & 35.72 \\
\hline TUR & 20,037 & 3,161 & 6,338 & 40.22 \\
\hline CAN & 10,228 & 10,519 & 972 & 53.93 \\
\hline $\mathrm{QC}$ & 3,673 & 10,369 & 354 & 53.11 \\
\hline ON & 3,377 & 10,432 & 324 & 52.72 \\
\hline $\mathrm{BC}$ & 906 & 10,803 & 84 & 58.81 \\
\hline $\mathrm{AB}$ & 867 & 10,965 & 79 & 55.95 \\
\hline MB & 448 & 10,880 & 41 & 54.14 \\
\hline SK & 329 & 11,256 & 29 & 53.74 \\
\hline NS & 226 & 10,566 & 21 & 53.17 \\
\hline NB & 191 & 9,985 & 19 & 53.59 \\
\hline $\mathrm{PE}$ & 151 & 10,494 & 14 & 54.02 \\
\hline NL & 64 & 10,778 & 6 & 70.74 \\
\hline AUS & 9,176 & 6,017 & 1,525 & 34.00 \\
\hline JPN & 7,290 & 8,607 & 847 & 93.15 \\
\hline
\end{tabular}

${ }^{1}$ EU-28 = European Union; DEU = Germany; FRA = France; GBR $=$ Great Britain; POL $=$ Poland; NLD = the Netherlands; ITA = Italy; IRL = Ireland; ESP = Spain; DNK = Denmark; BEL = Belgium; AUT = Austria; CZE $=$ Czechia $; \mathrm{SWE}=$ Sweden $; \mathrm{FIN}=$ Finland $; \mathrm{USA}=$ United States; $\mathrm{CA}=$ California $; \mathrm{WI}=$ Wisconsin $; \mathrm{ID}=$ Idaho; $\mathrm{NY}=$ New York; TX = Texas; $\mathrm{MI}=$ Michigan; PA = Pennsylvania; $\mathrm{MN}=$ Minnesota; $\mathrm{NM}=$ New Mexico; WA = Washington; $\mathrm{BRA}=$ Brazil; $\mathrm{CHN}=$ China; RUS $=$ Russia; $\mathrm{NZL}=$ New Zealand; TUR $=$ Turkey; CAN $=$ Canada; $\mathrm{QC}=$ Québec; $\mathrm{ON}=$ Ontario; $\mathrm{BC}=$ British Columbia; $\mathrm{AB}=$ Alberta $; \mathrm{MB}=$ Manitoba; $\mathrm{SK}=$ Saskatchewan; NS = Nova Scotia; PE = Prince Edward Island; NL = Newfoundland; AUS = Australia; JPN = Japan.

${ }^{2}$ Canadian production values: CDIC-Average production based on official-Supervised records (CDIC, 2019a). US annual production values: USDA ERS-Dairy data-Milk cows and production by state and region (USDA ERS, 2019). All other regions: CLAL.it - Dairy by country (CLAL, 2019).

${ }^{3}$ Canadian annual per cow production values: CDIC-Average production based on official-Supervised records (CDIC, 2019a). US production per cow values: USDA ERS-Milk cows and production by state and region (USDA ERS, 2019). All other regions: CLAL.it-Dairy by country (CLAL, 2019).

${ }^{4}$ Canadian cattle values: STATCAN-Table $32-10-0130-01-$ Number of cattle, by class and farm type $(\times 1,000)$ (STATCAN, 2020). US cattle values: USDA ERS-Dairy data-Milk cows and production by state and region (USDA ERS, 2019). All other regions: CLAL.it-Dairy by country (CLAL, 2019).

${ }^{5}$ Turkey: 2018 EU-28. Australian price: Australian Dairy Industry in Focus-2018 (Dairy Australia, 2019). Canadian values: CDIC-MI011-Canadian farm cash receipts from dairying (CDIC, 2019c). All other regions: CLAL.it-Dairy by country (CLAL, 2019). Converted to 2018 US\$ using IRS.gov-Yearly average currency exchange rates (IRS, 2020).

${ }^{6} 2017$ values. 
Table A2. Region-specific aggregated input variables used in the Monte Carlo simulations of the Mycobacterium avium ssp. paratuberculosispositive Markov herd model ${ }^{1}$

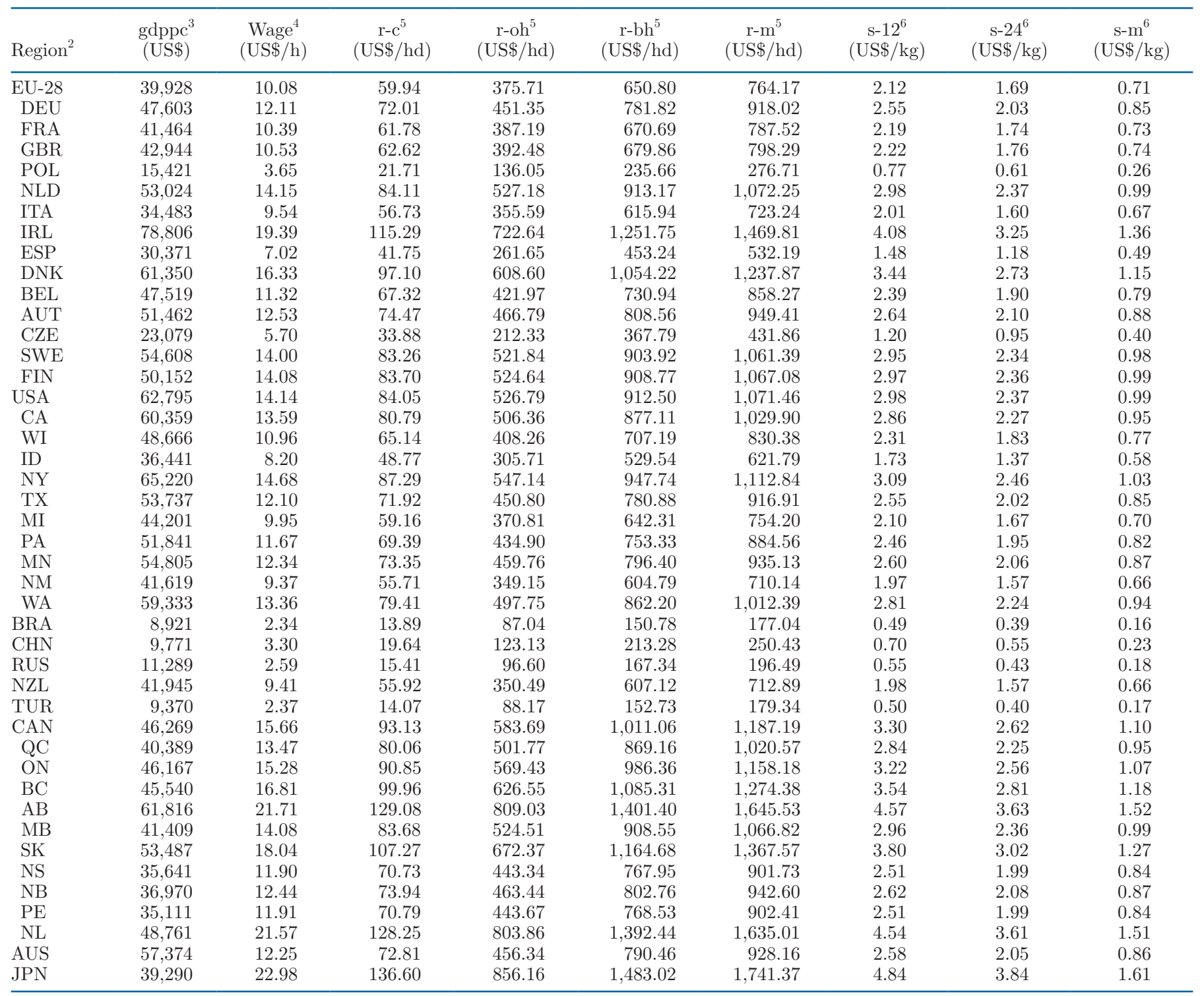

${ }^{1}$ All variables simulated with a normal distribution and standard deviation of $10 \%$ of the mean.

${ }^{2}$ EU-28 = European Union; DEU = Germany; FRA = France; GBR = Great Britain; POL = Poland; NLD = the Netherlands; ITA = Italy; IRL $=$ Ireland; ESP $=$ Spain; DNK = Denmark; BEL = Belgium; AUT = Austria; CZE = Czechia; SWE $=$ Sweden; FIN = Finland; USA = United States; CA = California; $\mathrm{WI}=$ Wisconsin; $\mathrm{ID}=$ Idaho; $\mathrm{NY}=$ New York; TX $=$ Texas; $\mathrm{MI}=$ Michigan; $\mathrm{PA}=$ Pennsylvania; $\mathrm{MN}=\mathrm{Minnesota}$; $\mathrm{NM}=$ New Mexico; WA = Washington; BRA = Brazil; CHN = China; RUS = Russia; NZL = New Zealand; TUR = Turkey; CAN = Canada; $\mathrm{QC}=$ Québec; $\mathrm{ON}=$ Ontario; $\mathrm{BC}=$ British Columbia; $\mathrm{AB}=$ Alberta; $\mathrm{MB}=$ Manitoba; $\mathrm{SK}=$ Saskatchewan; NS = Nova Scotia; PE = Prince Edward Island; NL = Newfoundland; AUS = Australia; JPN = Japan.

${ }^{3}$ Gross domestic product per capita (gdppc). US gdppc by state (BEA, 2019) and Canadian gross domestic product by province (STATCAN, 2019c). Converted to US\$ (IRS, 2020). All other regions (World Bank, 2020).

${ }^{4}$ Estimated aggregate dairy wage rate (wage). US 2018 (USDA NASS, 2019). All other regions ( $i$ through $n$ ) calculated using the following for-

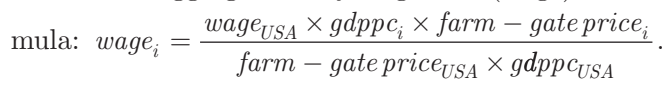

${ }^{5}$ hd $=$ head. Calf (c), open heifer (oh), bred heifer (bh), and mature cow (m) replacement (r) costs. US replacement prices (USDA, 2020). All

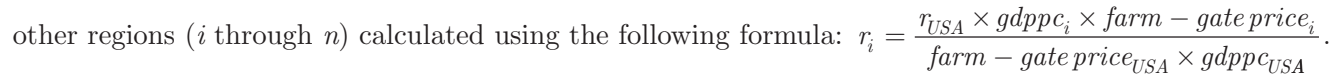

${ }^{6} 0$-12-mo animals (12), 12-24-mo animals (24), and mature cow (m) salvage (s) prices. Canadian salvage prices (STATCAN, 2019a). Converted to $\mathrm{kg}$ at $50.8023 \mathrm{~kg} / \mathrm{cwt}$ (hundredweight) and converted to US\$ (IRS, 2020). All other regions ( $i$ through $n$ ) calculated using the following formula: $s_{i}=\frac{s_{C A N} \times \text { gdppc }_{i} \times \text { farm }- \text { gate }_{\text {price }}}{\text { farm }- \text { gate price }_{\text {CAN }} \times \text { gdppc }_{\text {CAN }}}$. 
Table A3. Estimated mean value 10-yr average annual losses (US\$ per cow in Mycobacterium avium ssp. paratuberculosis-positive herds and millions of US\$ per region) across a range of prevalence scenarios

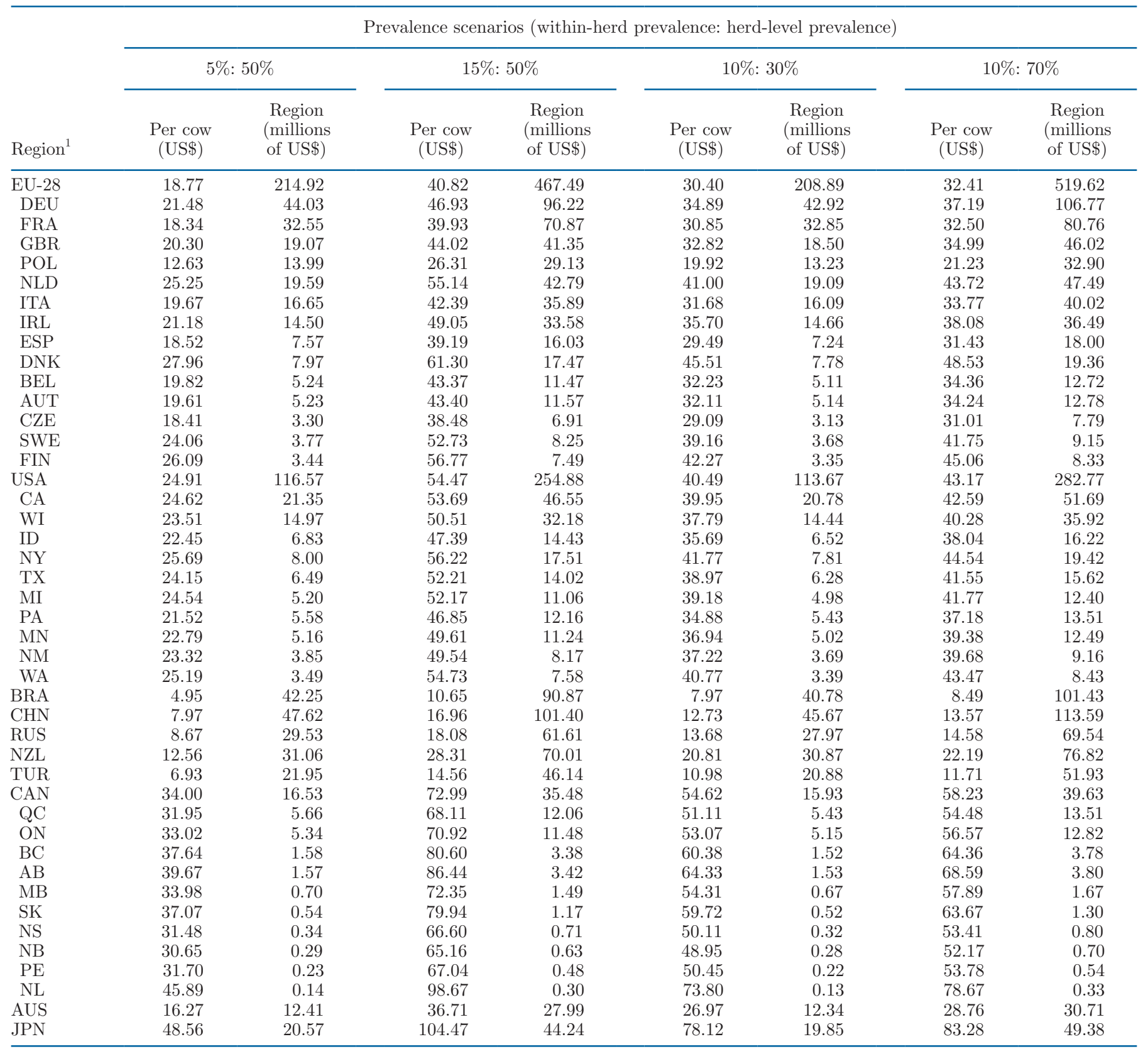

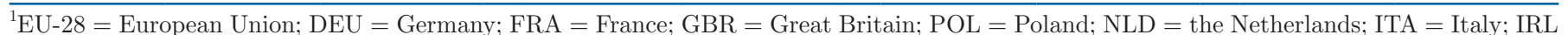
$=$ Ireland; $\mathrm{ESP}=$ Spain; DNK = Denmark; BEL = Belgium; AUT = Austria; $\mathrm{CZE}=$ Czechia; $\mathrm{SWE}=$ Sweden; FIN $=$ Finland; USA $=$ United States; CA = California; WI = Wisconsin; ID = Idaho; NY = New York; TX = Texas; MI = Michigan; PA = Pennsylvania; MN = Minnesota; $\mathrm{NM}=$ New Mexico; WA = Washington; BRA = Brazil; CHN = China; RUS = Russia; NZL = New Zealand; TUR $=$ Turkey; CAN = Canada; $\mathrm{QC}=$ Québec; $\mathrm{ON}=$ Ontario; $\mathrm{BC}=$ British Columbia; $\mathrm{AB}=$ Alberta; $\mathrm{MB}=$ Manitoba; $\mathrm{SK}=$ Saskatchewan; NS = Nova $\mathrm{Scotia} ; \mathrm{PE}=\mathrm{Prince}$ Edward Island; NL = Newfoundland; AUS = Australia; JPN = Japan. 
Table A4. Estimated sources of losses per cow in various dairyproducing regions assuming a Mycobacterium avium ssp. paratuberculosis herd-level prevalence of $50 \%$ and a within-herd prevalence $10 \%$

\begin{tabular}{|c|c|c|c|}
\hline \multirow[b]{2}{*}{ Region $^{1}$} & \multicolumn{3}{|c|}{ Proportion of losses } \\
\hline & $\begin{array}{l}\text { Premature } \\
\text { culling }\end{array}$ & $\begin{array}{c}\text { Reduced } \\
\text { salvage value }\end{array}$ & $\begin{array}{l}\text { Reduced } \\
\text { production }\end{array}$ \\
\hline EU-28 & 0.25 & 0.12 & 0.63 \\
\hline DEU & 0.26 & 0.12 & 0.61 \\
\hline FRA & 0.26 & 0.12 & 0.62 \\
\hline GBR & 0.24 & 0.11 & 0.64 \\
\hline POL & 0.14 & 0.06 & 0.80 \\
\hline NLD & 0.26 & 0.12 & 0.62 \\
\hline ITA & 0.23 & 0.11 & 0.67 \\
\hline IRL & 0.41 & 0.19 & 0.40 \\
\hline ESP & 0.18 & 0.08 & 0.74 \\
\hline DNK & 0.27 & 0.13 & 0.60 \\
\hline BEL & 0.27 & 0.12 & 0.61 \\
\hline AUT & 0.30 & 0.14 & 0.57 \\
\hline CZE & 0.15 & 0.07 & 0.78 \\
\hline SWE & 0.27 & 0.13 & 0.60 \\
\hline FIN & 0.25 & 0.12 & 0.63 \\
\hline USA & 0.27 & 0.12 & 0.61 \\
\hline $\mathrm{CA}$ & 0.26 & 0.12 & 0.62 \\
\hline WI & 0.22 & 0.10 & 0.68 \\
\hline ID & 0.17 & 0.08 & 0.74 \\
\hline NY & 0.27 & 0.12 & 0.61 \\
\hline TX & 0.24 & 0.11 & 0.66 \\
\hline MI & 0.19 & 0.09 & 0.72 \\
\hline PA & 0.25 & 0.12 & 0.63 \\
\hline MN & 0.25 & 0.12 & 0.63 \\
\hline NM & 0.19 & 0.09 & 0.72 \\
\hline WA & 0.25 & 0.11 & 0.64 \\
\hline BRA & 0.22 & 0.10 & 0.67 \\
\hline $\mathrm{CHN}$ & 0.20 & 0.09 & 0.71 \\
\hline RUS & 0.14 & 0.07 & 0.79 \\
\hline NZL & 0.34 & 0.16 & 0.50 \\
\hline TUR & 0.16 & 0.08 & 0.76 \\
\hline CAN & 0.22 & 0.10 & 0.68 \\
\hline $\mathrm{QC}$ & 0.20 & 0.09 & 0.71 \\
\hline ON & 0.22 & 0.10 & 0.68 \\
\hline $\mathrm{BC}$ & 0.21 & 0.10 & 0.69 \\
\hline $\mathrm{AB}$ & 0.26 & 0.12 & 0.63 \\
\hline MB & 0.20 & 0.09 & 0.71 \\
\hline SK & 0.23 & 0.11 & 0.66 \\
\hline NS & 0.18 & 0.08 & 0.74 \\
\hline NB & 0.19 & 0.09 & 0.72 \\
\hline $\mathrm{PE}$ & 0.18 & 0.08 & 0.74 \\
\hline NL & 0.22 & 0.10 & 0.68 \\
\hline AUS & 0.34 & 0.16 & 0.50 \\
\hline JPN & 0.22 & 0.10 & 0.67 \\
\hline
\end{tabular}

${ }^{1}$ EU-28 = European Union; DEU = Germany; FRA = France; GBR = Great Britain; POL = Poland; NLD = the Netherlands; ITA = Italy; $\mathrm{IRL}=$ Ireland; $\mathrm{ESP}=$ Spain $; \mathrm{DNK}=$ Denmark; $\mathrm{BEL}=$ Belgium; $\mathrm{AUT}=$ Austria; $\mathrm{CZE}=$ Czechia $; \mathrm{SWE}=$ Sweden $; \mathrm{FIN}=$ Finland; $\mathrm{USA}=$ United States; CA $=$ California; $\mathrm{WI}=$ Wisconsin; $\mathrm{ID}=$ Idaho; $\mathrm{NY}=$ New York; TX $=$ Texas; $\mathrm{MI}=$ Michigan; PA = Pennsylvania; $\mathrm{MN}=$ Minnesota; $\mathrm{NM}=$ New Mexico; $\mathrm{WA}=$ Washington; $\mathrm{BRA}=$ Brazil; CHN = China; RUS = Russia; NZL $=$ New Zealand; TUR $=$ Turkey; $\mathrm{CAN}=$ Canada; $\mathrm{QC}=$ Québec; $\mathrm{ON}=$ Ontario $; \mathrm{BC}=$ British Columbia; $\mathrm{AB}=$ Alberta; $\mathrm{MB}=$ Manitoba; $\mathrm{SK}=$ Saskatchewan; NS $=$ Nova Scotia; $\mathrm{PE}=$ Prince Edward Island; $\mathrm{NL}=$ Newfoundland; AUS $=$ Australia; JPN = Japan.
Table A5. Estimated mean value annual losses (US\$ per cow in Mycobacterium avium ssp. paratuberculosis-positive herds and millions US\$ per region) with an assumed stable within-herd prevalence of $10 \%$ and a herd-level prevalence of $50 \%$

\begin{tabular}{|c|c|c|c|}
\hline Region $^{1}$ & $\begin{array}{l}\text { Annual losses } \\
\text { (US\$ per cow) }\end{array}$ & $\begin{array}{c}\text { Annual losses } \\
\text { (\% of milk revenue) }\end{array}$ & $\begin{array}{l}\text { Annual losses } \\
\text { (millions of US\$ } \\
\text { per region) }\end{array}$ \\
\hline EU-28 & 27.67 & 0.95 & 316.89 \\
\hline DEU & 31.67 & 0.97 & 64.94 \\
\hline FRA & 27.11 & 0.96 & 48.12 \\
\hline GBR & 29.93 & 0.93 & 28.12 \\
\hline POL & 18.60 & 0.77 & 20.59 \\
\hline NLD & 37.24 & 0.97 & 28.90 \\
\hline ITA & 28.99 & 0.90 & 24.54 \\
\hline IRL & 31.30 & 1.40 & 21.43 \\
\hline ESP & 27.28 & 0.83 & 11.16 \\
\hline DNK & 41.23 & 0.99 & 11.75 \\
\hline BEL & 29.23 & 0.98 & 7.73 \\
\hline AUT & 28.94 & 1.04 & 7.71 \\
\hline CZE & 27.10 & 0.78 & 4.87 \\
\hline SWE & 35.48 & 0.99 & 5.55 \\
\hline FIN & 38.46 & 0.95 & 5.08 \\
\hline USA & 36.74 & 0.97 & 171.92 \\
\hline $\mathrm{CA}$ & 36.31 & 0.96 & 31.48 \\
\hline WI & 34.64 & 0.89 & 22.07 \\
\hline ID & 33.06 & 0.82 & 10.07 \\
\hline NY & 37.89 & 0.98 & 11.80 \\
\hline TX & 35.60 & 0.91 & 9.56 \\
\hline MI & 36.15 & 0.84 & 7.66 \\
\hline PA & 31.73 & 0.95 & 8.23 \\
\hline $\mathrm{MN}$ & 33.61 & 0.95 & 7.61 \\
\hline NM & 34.35 & 0.84 & 5.67 \\
\hline WA & 37.14 & 0.94 & 5.14 \\
\hline BRA & 7.30 & 0.89 & 62.27 \\
\hline CHN & 11.74 & 0.85 & 70.15 \\
\hline RUS & 12.76 & 0.78 & 43.47 \\
\hline NZL & 18.54 & 1.17 & 45.86 \\
\hline TUR & 10.20 & 0.80 & 32.32 \\
\hline CAN & 50.11 & 0.88 & 24.36 \\
\hline $\mathrm{QC}$ & 47.07 & 0.85 & 8.34 \\
\hline ON & 48.67 & 0.88 & 7.88 \\
\hline $\mathrm{BC}$ & 55.46 & 0.87 & 2.33 \\
\hline $\mathrm{AB}$ & 58.50 & 0.95 & 2.31 \\
\hline MB & 50.06 & 0.85 & 1.03 \\
\hline SK & 54.64 & 0.90 & 0.80 \\
\hline NS & 46.36 & 0.83 & 0.50 \\
\hline NB & 45.15 & 0.84 & 0.43 \\
\hline $\mathrm{PE}$ & 46.69 & 0.82 & 0.34 \\
\hline NL & 67.63 & 0.89 & 0.20 \\
\hline AUS & 24.03 & 1.17 & 18.32 \\
\hline JPN & 71.57 & 0.89 & 30.31 \\
\hline
\end{tabular}

${ }^{1}$ EU-28 = European Union; DEU = Germany; FRA = France; GBR = Great Britain; $\mathrm{POL}=$ Poland; $\mathrm{NLD}=$ the Netherlands; ITA $=$ Italy; $\mathrm{IRL}=$ Ireland $; \mathrm{ESP}=$ Spain $; \mathrm{DNK}=$ Denmark; $\mathrm{BEL}=$ Belgium; $\mathrm{AUT}=$ Austria; $\mathrm{CZE}=$ Czechia $; \mathrm{SWE}=$ Sweden $; \mathrm{FIN}=$ Finland; $\mathrm{USA}=$ United States; CA $=$ California $; \mathrm{WI}=$ Wisconsin; $\mathrm{ID}=$ Idaho; $\mathrm{NY}=$ New York; $\mathrm{TX}=$ Texas; $\mathrm{MI}=$ Michigan; $\mathrm{PA}=$ Pennsylvania; $\mathrm{MN}=$ Minnesota; $\mathrm{NM}=$ New Mexico; WA = Washington; BRA = Brazil; CHN $=$ China; RUS $=$ Russia; NZL $=$ New Zealand; TUR $=$ Turkey; $\mathrm{CAN}=$ Canada; $\mathrm{QC}=$ Québec; $\mathrm{ON}=$ Ontario; $\mathrm{BC}=$ British Columbia; $\mathrm{AB}=$ Alberta; $\mathrm{MB}=$ Manitoba; $\mathrm{SK}=$ Saskatchewan; NS $=$ Nova Scotia $; \mathrm{PE}=$ Prince Edward Island; NL = Newfoundland; AUS $=$ Australia; JPN $=$ Japan. 
Table A6. Estimated sources of losses per cow in Canadian regions assuming a Mycobacterium avium ssp. paratuberculosis herd-level prevalence of $50 \%$ and a within-herd prevalence 10\%, and with consideration for supply management (fixed output over time and production losses allocated as increased variable costs necessary to maintain production)

\begin{tabular}{lccc}
\hline & \multicolumn{3}{c}{ Proportion of losses } \\
\cline { 2 - 4 } Region $^{1}$ & Premature culling & Reduced salvage value & Reduced production \\
\hline CAN & 0.35 & 0.16 & 0.48 \\
QC & 0.33 & 0.15 & 0.52 \\
ON & 0.37 & 0.17 & 0.47 \\
BC & 0.32 & 0.15 & 0.53 \\
AB & 0.37 & 0.17 & 0.46 \\
MB & 0.30 & 0.14 & 0.56 \\
SK & 0.36 & 0.17 & 0.48 \\
NS & 0.30 & 0.14 & 0.56 \\
NB & 0.31 & 0.15 & 0.54 \\
PE & 0.33 & 0.15 & 0.52 \\
NL & 0.32 & 0.53 \\
\hline${ }^{1}$ CAN = Canada; QC $=$ Québec; ON = Ontario; BC = British Columbia; AB = Alberta; MB = Manitoba; SK
\end{tabular}

$=$ Saskatchewan; NS = Nova Scotia $; \mathrm{PE}=$ Prince Edward Island; NL = Newfoundland.

Table A7. Estimated mean value 10-yr average annual losses (US\$ per cow in Mycobacterium avium ssp. paratuberculosis-positive herds and millions US\$ per region) for Canadian dairy across a range of prevalence scenarios, and with consideration for supply management (fixed output over time and production losses allocated as increased variable costs necessary to maintain production)

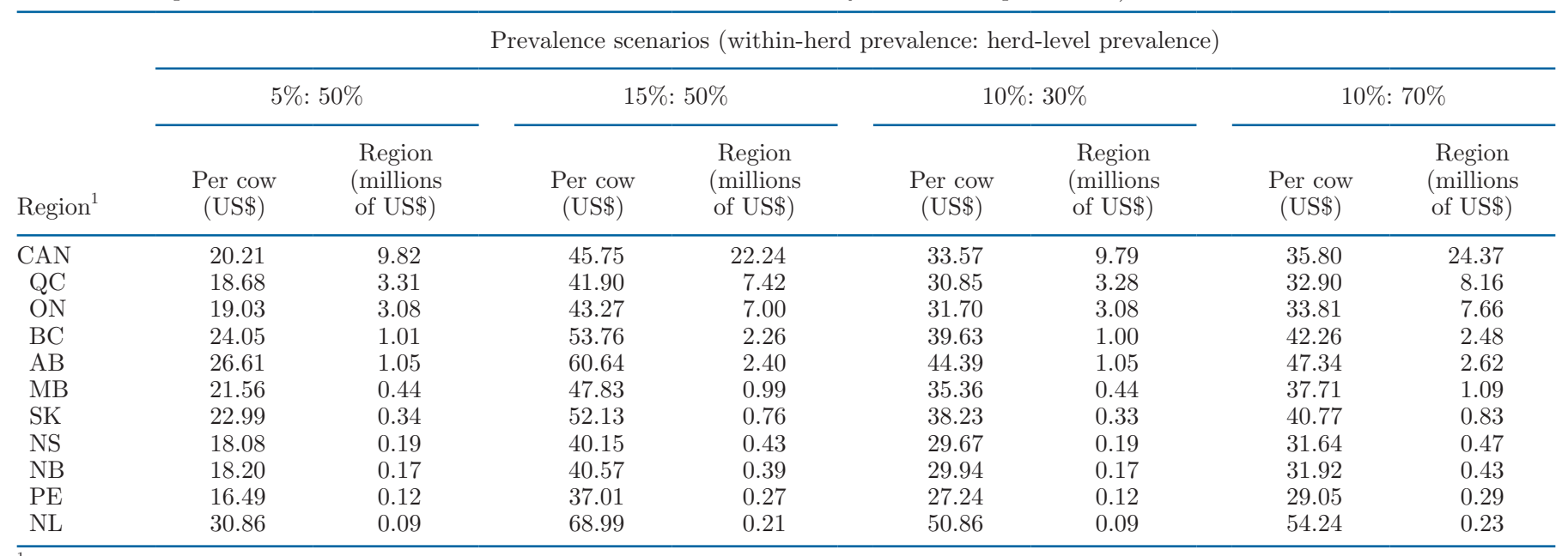

${ }^{1} \mathrm{CAN}=$ Canada; $\mathrm{QC}=$ Québec; $\mathrm{ON}=$ Ontario; $\mathrm{BC}=$ British Columbia; $\mathrm{AB}=$ Alberta; $\mathrm{MB}=\mathrm{Manitoba} ; \mathrm{SK}=\mathrm{Saskatchewan} ; \mathrm{NS}=\mathrm{Nova}$ Scotia; PE = Prince Edward Island; NL = Newfoundland. 